$11-1-2006$

\title{
The Problem of Social Cost in a Genetically Modified Age
}

\author{
Paul J. Heald \\ University of Georgia School of Law, heald@uga.edu \\ James C. Smith \\ University of Georgia School of Law, jim@uga.edu
}

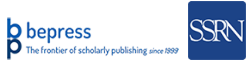

\section{Repository Citation}

Paul J. Heald and James C. Smith, The Problem of Social Cost in a Genetically Modified Age (2006), Available at: https://digitalcommons.law.uga.edu/fac_artchop/8

This Article is brought to you for free and open access by the Faculty Scholarship at Digital Commons @ University of Georgia School of Law. It has been accepted for inclusion in Scholarly Works by an authorized administrator of Digital Commons @ University of Georgia School of Law. Please share how you have benefited from this access For more information, please contact tstriepe@uga.edu. 
government is the problem, not the solution to our problems. ${ }^{151}$ From this perspective, deciding to openly abandon the traditional rule that an advertisement is not an offer reflects a statement about ideology and politics as well as contract doctrine. An advertisement is an offer because it is right for the public to expect, the legislature to dictate, and the courts to enforce standards of fairness in the marketplace.

\section{The Problem of Social Cost In a Genetically Modified Age}

Paul J. Heald* and James Charles Smrth***

\section{INTRODUCTION}

One fundamental impetus for the development of modern law stems from the need to settle disputes between neighbors. Indeed, the focus of the most-cited article in law review history,' Ronald Coase's The Problem of Social Cost, ${ }^{2}$ is firmly on the issue of how the law should deal with someone who interferes with the use of a neighbor's property. The myriad of uses to which Coase's analysis has been put over the last forty years ${ }^{3}$ has obscured the relatively straightforward nature of the question that interested him: Should the law force an entity to bear the full cost of its behavior? When one neighbor harms another, should the law impose liability in the form of a damages action, or in the form of a tax (as suggested famously by Pigou $^{4}$ ), or, perhaps, do nothing at all?

The original conundrum contemplated by Coase arises with spectacular clarity in the context of the emerging problem of pollen drift.

- Allen Post Professor of Law, University of Georgia.

*. John Byrd Martin Professor of Law, University of Georgia.

We would like to thank Maggie Rentz for her research assistance and Robert Bartlett, Omri Ben-Shahar, Andrew Brod, Dan Burk, Kelly Casey, Becky Eisenberg, Wally Hellerstein, Douglas Laycock, Mark Lemley, Andrew Kull, Jason Solomon, and participants at the November 2005 meeting of the working group on Property, Citizenship, and Social Entrepreneurisn for their comments on the project.

1. Fred R. Shapiro, The Most-Cited Law Review Articles Revisited, 71 ChL-Kent L. Rev. 75I, 767 (1996).

2. RH. COAsE, The Problem of Sacial Cost, 3 IL \& Econ, I (1960), reprinted in THE FIaw, rue MAEKET, AND THE LAW 95 (1988)

3. See, e.g., David Dudley, The Coase Theorem as Applied to Trade Barriers and Optimal Adjustment Strategies, I9 U. PA. J. INT'L. Econ. L. 1029 (1998); Paul E. McGreal \& DeeDee Baba, Applying Coase to Qui Tam Actions Against the States, 77 Notre Dame L. Rev. 87 (2001). Westlaw currently retrieves seventy-one law documents in its law journal database (JR) that contain the words "Coase" or "Consean" in their titles.

4. See A.C. Ploov, The Economics of Welfare 127-30 (4th ed. r932).

151. See Feinman, Conservative Campaign, supra note 149, at 7-10; Feinman, Classical Revival, supra note 149 , at $55-59$. 
Genetically modified (GMO) crops constitute a significant segment of agricultural production, and pollen from these crops drifts inexorably across property lines. ${ }^{5}$ Consider the situation faced by farmers in the United States who grow non-genetically modified (non-GMO) crops for buyers in jurisdictions that heavily regulate or forbid the sale of genetically modified food products, like the European Union or Japan, or who sell to purveyors of organic food products in the United States or elsewhere. The market for non-GMO crops is enormous, ${ }^{6}$ and such goods often command a premium price, ${ }^{7}$ but due to the widespread planting of GMO crops, non-GMO farmers run the constant risk of contamination by pollen from patented genetically modified plants." If a farmer has a forward contract for non-GMO corn for sale in Europe, and her corn fields are pollinated by a neighbor's genetically modified crop, then the anticipated premium ${ }^{10}$ from selling the non-GMO crop will be lost. More

5. See infra notes $86-87$ and accompanying text.

6. See infra Part II.B. Japan and the European Union are two obvious markets, but even large American buyers, like Gerber baby foods, are going non-GMO. See Drew L. Kershen, The Risks of Going Non-GMO, 53 OkLA. L. REv. 631, 633 (2000) ("In September 1999, Gerber announced that its baby food products would no longer use any ineredients from genetically modified crops." ); see also Frito Lay Asks Farmers Not to Grow Altered Corn: Firm Playing it Safe Despite FDA Assurunces, Dallus Moesino News, Jan. 28, 2000, at IID ("Snack maker Frito-Lay Inc. has asked its hundreds of contract farmers to grow corn that has not been genetically modified in case U.S. consumers shy bioengineered foods.")-

7. See Int'L Trade Ctro, Food a Agiac. Org, of tue Unmed Nations, World Markets for Organic Frutr and Vegetables 215 (2001) (premium for organic produce in conventional stores in the United States ranges from $11 \%$ to $121 \%$ ); Carie-Megan Flood, Pollen Drift and Potential Causes of Action, $28 \mathrm{~J}$. Cokp. L 473. 474 (2003) (noting price of organic com at $\$ 4$ per bushel, while genetically modified corn sold for \$1.67); Stephen M. Scanlon, Comment, Should Missouri Farmers of Geverically Modified Crops Be Held Liable for Genetic Drift and Crass-Pollination? no Mo. Evvrt Generically REv, I, I (2002) ("Farmers who cultivate organic crops stand to earn a substantial premium in these markets if their crops can pass a rigorous testing procedure for GMOs. It is this market premiun ayailable on organic crops that makes the concept of 'pollen drift' such a signifieant threat to oremic farmers.").

8. See CTr. For Food SAFETy, Monsanto vs. U.S. Fabereas 8-9 (2005) (noting that in 2004, GMO crops made up $85 \%$ of the United States soy acreage, $45 \%$ of the corn acreage, and $76 \%$ of the cotton acreage; in 2003 , they composed $84 \%$ of the canola acreage).

9. See Margaret Rosso Grossman, Biotechnology, Property Rights and the Environment, 50 AM. J. Comp. L. Supp. 215,229 (2002).

One incident of cross-pollination involved Bt corn, cultivated in Texas, that contaminated the fields of a certified organic farmer. Terra Prima, a Wisconsin food processing company. Europe. DNA testing revealed traces of Bt corn, and the food company had to destroy 187,000 tags of chips, worth over $\$ 100,000$.

Id; see also Richard A. Repp, Comment, Biotech Polluntion: Assersing Liability for Genetically Modified Crop Production and Genetic Drift, 36 IDano L. Rev. 585, 591-93 (2000) (describing other incidents of contamination).

10. See supra note 7 and accompanying text. importantly, the non-GMO farmer may find herself unable to sell the contaminated crop at all. If her plants are now found to contain patented cell structures claimed by the patentee of the GMO corn, then the farmer is arguably a patent infringer and selling her crop without the patentee's permission will be fraught with risk.

The possibility of patent law exacerbating the harm done to the victim of this type of pollution adds an intriguing twist to the original problem. Although the fact of contamination through pollen drift is very real for non-GMO farmers, the danger posed by patent law may seem far-fetched because, in most areas of the law, passive bystanders" have a complete defense. ${ }^{12}$ Patent law, however, is based on the concept of strict liability. ${ }^{13}$ If a department store sells an infringing product, for example, the store is liable whether it knew the product was infringing or not. ${ }^{14} \mathrm{~A}$ scientist working in her lab is guilty of patent infringement even if she has no idea that the new compound she has just synthesized happens to fall within the claims of an existing patent.

Monsanto Corporation, the world's leading agricultural biotech company, ${ }^{15}$ has been particularly active in using federal law to police anyone it finds to be growing its patented plants. ${ }^{16}$ For instance, in the famous Schmeiser litigation, ${ }^{17}$ Monsanto, and other commentators, took the position that a bystanding farmer could be liable for patent

11. Whenever we use the phrase "bystanding farmer," we refer to a farmer whose fields have been contaminated by unwanted genetic material against the will of the farmer.

12. See infra notes $287-291$ and accompanying text (discussing innocent bystanders in the contex of criminal law)

13. See Jurgens v. CBK, Ltd., 80 F. .3d 1566, 1570 n.2 (Fed. Cir. 1996) ("Infringement ... is a stric liability offense .... and a court must award damages adequate to compensate for the infringement ... regardless of the intent, culpability, or motivation of the infringer.").

14. Sec Roger D. Blair \& Thomas F. Cotter, An Economic Analysis of Seller and User Liability in Intellectual Property Law, 68 U. CIN. L. REv. I, 6 (1999) ("Because patent infringement [like copyright and trademark infringement] is a strict liability tort, the patentee may enjoin the unauthorized manufacture, use, or sale of the invention, regardless of the infringer's state of mind.")

15. Monsanto has $85 \%$ of its research and development budget, or $\$ 430$ million annually, invested in biotechnology. See CTr. FOR FooD SAFrT, supra note 8, at 7. The company "currently holds 647 biotech plant patents, more than any other biotech company." Id. at Ir. Monsanto's GMO crops have been more successful than any other biotech company's, supplying the technology for $90 \%$ of the world's GMO crops. See Monsanto Co., 2004 AnnunL. Report 1 (2004).

I6. See CTr. por Foon SArtTr, supra note 8, at 4; Drew L Kershen, Of Straying Crops and Patent Rights, 43 W ASHBunn L.J. 575, 582-83 (2004)

17. Monsanto Can., Inc, v. Schmeiser, $[2004]$ I S.C.R. 902, 936 (Can.). Although the defendant canola farmer claimed to be an innocent bystander, the court found that he deliberately planted seeds that he knew to be infringing. Id. The seeds might have been innocently produced by Schmeiser's plants due to pollen drift, but the court found it unnecessary to determine bow the infringing seeds were produced in the first place, given that Schmeiser knowingly saved and deliberately planted them. 
infringement stemming from windblown GMO pollen. ${ }^{18}$ In fact, Monsanto's lead in its industry is certainly due in part to its use of forceful investigations and prosecutions against those it suspects of patent infringement, regardless of whether such infringers act willfully or are even aware of their alleged infringement. ${ }^{19}$ In short, Monsanto is in the unique position of being able to take a problem that it created - the contamination of non-GMO plants by pollen drift from GMO plantsand use it to its advantage by prosecuting those bystanding farmers whose crops become contaminated. ${ }^{20}$

Although some articles have discussed the phenomenon of pollen drift, ${ }^{2 t}$ none have undertaken any sort of economic analysis or even accurately analyzed the important patent law issues presented. Commentators have done a better job canvassing the potential for state law counterclaims to be made by bystanding victims of pollen drift, ${ }^{22}$ but

18. Id.; see also Leora Broydo, The Trouble With Percy, Mothra Jones (Dec. 13, 2000) http://www.motherjones.com/news/feature/200o/I2/schmeiser.htmL

In many ways, the law is on Monsanto's side in this case. Under patent law, it doesn't really matter whether Schmeiser knew what he was doing or not, he's still an "infringer," says Dan
Burk, a professor at the University of Minnesota Law School who specializes in 1.

19. See CrR. FOR Food SAfETy, supra note 8, at 4-5.

20. Monsanto devotes seventy-five full-time employees and $\$$ to million per year to prosecutions and investigations. It is believed that actions and investigations by Monsanto against farmers number into the thousands, with most settling outside of court in confidential agreements. Id. at 4. Genernlly, the company initiates between five hundred and six hundred new investigations each year, many of which are the result of tips called in to the company's toll-free hotline. Id at 23-24. Farmers repor that investigators often go onto the lands without permission, sometimes arrive with police escorts, sometimes even conduct clandestine surveillance of the farmers' premises. If at 24 . There have been approximately ninety actual lawsuits filed by Monsanto against United States farmers, involving 147

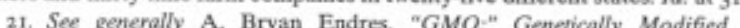

21. See generally A. Bryan Endres, "GMO:" Genetically Modified Organism or Gigantic Monctary Obigation? The Liability Schemes for GMO Damage in the United States and the European Kershen, supra note 16r Maria Lee \& Robert Burrell, Lieod, supna note 7, Grossman, supna note

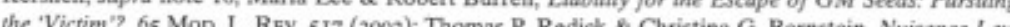
and the Prevertion of "Genetic Pollution": Declining a Dinner Date With Darister, 30 ELR News Avatrsas 10328 (2000); Repp, Patersing $10328(2000)$, Repp, supra note 9 , Norman Siebrasse, The innocent Bystander Probtem in the Patening of Higher Life Forms, 49 McGill LJ. 349 (2004), Marcia E. DeGecr, Comment, Can Roundup Ready iserds Ever Be Corralledt: Restraining Genetic Drift Through Criminal Sanctions, 29

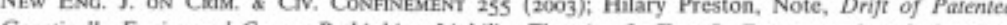
Genetically Engineered Crops: Rethinking Liability Theories, 81 TEx. L. REv. 1153 (2003); Scanlon, stapra note 7 .

2. See Endres, supra note 21, at $482-93$; Flood, supra note 7, at $482-97$, Grossman, supra note 9. at $227-38$; Kershen, supra note 16 , at $600-605$; Lee \& Burrell, supra note 21 , at 529-35; Redick \& Bernstein, supra note 21, at t0339-10342; Repp, supra note 9, at 600-20; Scanlon, supra note 7, at 210; Preston, supra note 21, at II65-1167. without reference to the much-needed economic framework provided by The Problem of Social Cost. In Part I of this Article, we apply the Coase Theorem and its most useful corollary to the problem of pollen drift. We conclude that the liability of pollen polluters should be governed by balancing rules under nuisance law, to be applied on a case-by-case basis, rather than by a blanket liability or immunity rule. We also conclude that truly bystanding non-GMO farmers should have a viable defense to patent infringement because liability would result in the application of a reverse Pigovian tax that cannot be justified under accepted economic theory. Only a contextual approach can account for the wide variety of costs that must be identified before determining whether liability for genetic pollution is socially desirable.

In the rest of this Article, we demonstrate that existing legal doctrines support the adoption of the framework we advocate. In order to do that more effectively, we briefly provide the background science of genetically modified plants and how their patented characteristics can be adventitiously transferred, and we also highlight the consequences of pollen drift by canvassing the multi-billion dollar market for non-GMO crops $^{23}$ Then, we discuss the common law nuisance and trespass doctrines that may provide farmers with an affirmative cause of action when pollen drift causes a reduction in the value of a planted crop. ${ }^{24}$ Finally, we discuss patent law defenses that may be available to patent infringement defendants who characterize themselves as victims of pollen drift (bystanding farmers). ${ }^{25}$ We find significant opportunities for true bystanding farmers to rebut patent infringement claims in the voluntary act doctrine and in the doctrines of patent misuse, unclean hands, and volenti non fit injuria. In the spirit of truly descriptive law and economics analysis, we conclude that applicable common law and equitable doctrines appear to be efficient.

\section{The Economics of Neighboring Farmers}

Coase begins The Problem of Social Cost with a succinct reminder of his primary concern, "[t]hose actions of business firms which have harmful effects on others. ${ }^{, 26}$ He then notes the conventional wisdom of the time, which held that liability (or some sort of tax) should necessarily be imposed on those who cause damage to their neighbors. ${ }^{27}$ Through a

\footnotetext{
23. See infra Part II.

4. See infra Part III.

25. See infra Part IV.

26. CONSE, supra note 2, at 95 .

27. Id
} 
series of examples, the most prominent of which involve damage done to neighboring farmers by wandering cattle and incendiary railroad sparks, ${ }^{20}$ he shows that in a world without transaction costs the automatic imposition of liability is socially undesirable (e.g., has negative welfare effects). If transacting is costless, neighbors will agree to an arrangement that maximizes social welfare, regardless of whether one neighbor has the legal right to harm or the other has the legal right to be free from harm. This is the primary thrust of the Coase Theorem, although it is not labeled as such in his original paper. ${ }^{29}$ Since it is hardly intuitive, we apply Coase's insight about a world without transaction costs to several scenarios involving pollen drift. Then we move on to the real world, a world of costly transactions, which Coase also discusses at length in his seminal paper. In that world, the initial assignment of rights and therefore the liability rule chosen, matter significantly.

A. Pollen Drift in a World with No Transaction Costs

Let us imagine an organic farmer, first farming alone, then confronted with a neighbor who plants GMO corn. We illustrate that assuming zero transaction costs, the net social benefit ${ }^{30}$ from their farming operations are the same regardless of the liability rule chosen.

\section{Solo Farme}

The first player is an organic farming operation that plants nonGMO corn on ten acres of land. Without interference, the organic farming firm expends $\$ 20$ producing thirty bushels of corn that will sell for $\$ 4$ per bushel. In order to get the $\$ 4$ per bushel price, the farmer must not only plant non-GMO seed, but must also forego the use of pesticides, herbicides, and non-organic fertilizer. The net value of the corn produced is $\$ 100$.

28. Id. at 97-104 (discussing cattle straying onto farmer's land and destroying crops); id. at 137-43 (discussing sparks from railway that destroy farmer's crop).

29. In a subsequent essay, Coase ascribes the naming of his theorem to George Stigler. See R.t. Coase, Notes on the Problem of Social Cost, in The Firm, THE MARKET, AND THE LAw 157, 157 (1988). He summarizes "the essence of the Coase Theorem" as "the delimitation of rights is an essential prelude to market transactions.... the ultimate result (which maximizes the value of production) is independent of the legal decision." Id. at I58. Stigler's formulation, acceptable to Coase, is somewhat different: "[U]nder perfect competition private and social costs will be equal." Id

30. In this Part we will generally ignore third-party wealth effects, such as the effect of legal rules everning pollen dritt on global plant diversity or on the income of patentees. Those issues ate addressed at the end of this Part.

\section{Scenario I.O: SOLO FARMER}

Organic Farme

Io Acres/3o Bushels

$(\$ 4 /$ bushel $x 30)-\$ 20$ Cost of Production [C.O.P.] $=\$ 100$

\section{Two Farmers/No Liability}

When a GMO farming firm moves next to the organic firm, the scenario changes. The GMO firm also plants ten acres of corn, but its corn is genetically modified to be highly productive if expensive herbicides, pesticides, and chemical fertilizers are used properly. The GMO firm will harvest one hundred bushels, but its costs of production are high $(\$ \mathrm{IOO})$ and it can only sell its corn for $\$ 2$ per bushel. ${ }^{31}$ The net value of the corn it produces is therefore $\$ 100 .^{32}$ Unfortunately for the neighboring organic firm, GMO pollen blown from the new farm contaminates its crop. This means that the organic farm will now only be able to collect the \$2 per bushel price for GMO corn when it delivers its 30 bushel harvest to market. Its profit will only be $\$ 40$ (\$60 - \$20 C.O.P.), unless the law provides it some sort of remedy. Under a regime which imposes no liability on the GMO farmer, the net value of corn produced by the two firms is $\$ 140$, as illustrated below:

\section{Scenario 2.o: No LIABILITY}

GMO FARMER

Io Acres/100 Bushels

Io Acres/3o Bushels

/bushel $x$ 100) $-\$ 100$ C.O.P. $=\$ 100 \quad(\$ 2 /$ bushel $x$ 30 $)-\$ 20$ C.O.P. $=\$ 40$

JoINT PRODUCTION $=\$ 140$

Note that the organic farming firm should be willing to pay up to $\$ 60$ to the GMO farmer not to plant GMO seed that will contaminate its fields and drive down the value of its corn. For example, assume that the GMO firm could switch to a non-GMO seed that would reduce its production from one hundred to eighty bushels (and lower its costs of production to $\$ 90$ because the seed is cheaper). If transactions between the farmers are costless, then we might see the organic farmer paying, for example, $\$ 30$ to the GMO farmer to plant the alternative non-GMO

31. See Flood, supra note 7, at 474 (discussing the lower price received by sellers of GMO corn).

32. Although it is not necessary to assume that both organic and non-organic farmers acting alone will earn the same, setting the values equal allows us to disregard altruistic reasons why a farmer might chose one form of farming over the other. 
seed. In that case, the GMO farmer would still make \$Ioo, while the organic farmer would make \$7o. We assume that the GMO farmer who switches to a non-GMO seed does not also become an organic farmer, which would require him to forego the use of pesticides, herbicides, and artificial fertilizers - a much more costly transformation. ${ }^{33}$ Notice that under these assumptions, the net value of production in this case rises to $\$ 170$, as illustrated below:

Scenario 2.I: No LiabILITY + Low SwITChING Costs

GMO FARMER

Organic Farmer

I0 Acres/80 Bushels

I0 Acres/30 Bushels

$(\$ 2 /$ bushel $x 80)-\$ 90$ C.O.P. $+\$ 30=\$ 100 \quad\left(\$ 4 /\right.$ bushel $\left.x_{30}\right)-\$ 20$ C.O.P. $-\$ 30=\$ 70$ Jolnt Production $=\$ 170$

In order to understand the importance of our present assumption of zero transaction costs, we note that the value of joint production would fall back to \$I 40 if the cost of negotiating a deal between the GMO and the organic farmer were more than $\$ 30 .^{34}$ If the cost were greater than $\$ 30$, a deal could not be made that would benefit both parties; therefore, there would be no agreement and the resulting joint production would be the same as Scenario 2.0.

Consider one final permutation of the no-liability scenario. In Scenario 2.I above, the GMO farmer's cost of switching to a different activity (planting an alternative seed) was \$30. If switching costs are sufficiently low for the organic farming firm, it might be inducedwithout having to transact with its neighbor-to plant GMO seeds. Under a zero switching costs scenario, the joint value of the corn produced will be $\$ 200$, as illustrated below:

\section{Scenario 2.2: No LiabILITY + Zero SwITCHING CostS}

\section{GMO FARMER}

Io Acres/I00 Bushels

Organic Farmer

JoINT Production $=\$ 170$

To summarize, under a regime of no liability for pollen contamination, the joint value of corn produced will be $\$ 140, \$ 170$, or $\$ 200$, depending on the relative switching costs assumed in the above hypotheticals.

\section{Two Farmers/Liability}

Under an alternative legal regime of liability for pollen contamination, the joint values of the corn produced will be exactly the same under the same set of assumptions. Consider first how liability would change the outcome for the GMO farming firm. It would still produce roo bushels of corn that it could sell for $\$ 2$ per bushel, but it would have to pay $\$ 60$ in damages to the organic farmer who was forced to sell his thirty bushels for the $\$ 2$ per bushel GMO price, as opposed to the $\$_{4}$ per bushel organic price. The damages paid to the organic farmer will allow him to receive the net $\$$ roo profit he was making before his neighbor arrived. The value of their joint production is $\$ 140$, as illustrated below:

\section{Scenario 3.o: LiabiLITy}

GMO FARMER

Organic Farmer

I0 Acres/roo Bushels

Io Acres/30 Bushels

$(\$ 2 /$ bushel $x$ 100 $)-\$ 100$ C.O.P. $-\$ 60=\$ 40\left(\$ 2 /\right.$ bushel $\left.x_{30}\right)-\$ 20$ C.O.P. $+\$ 60=\$ 100$ JorNt Production $=\$ 140$

Given the above scenario, the GMO farming firm is likely to consider alternatives to planting GMO corn seeds in order to avoid paying the $\$ 60$ in damages to the organic farmer. If, as assumed in Scenario $2 . \mathrm{I}$, it can switch to a non-GMO seed and produce eighty bushels of corn instead of one hundred, it will have an incentive to do so. Note that the joint value of production would rise to $\$ 170$, as illustrated below:

Scenario 3.I: LIABILITY + Low SwITCHING CosTs

GMO FARMER

Io Acres $/ 80$ Bushels
$(\$ 2 /$ bushel $\times 80)-\$ 90$ C.O.P. $=\$ 70$

I0 Acres/30 Bushels

JoINT Production $=\$ 170$

33. However, if he could switch all the way to organic farming, as in Scenario 3.2 infra, he would receive $\$ 4$ per bushel instead of $\$ 2$.

34. This is because the organic farmer will spend no more than $\$ 60$ to prevent $\$ 60$ worth of damage, and the GMO farmer must be paid at least $\$ 30$ in order to change. Therefore, any negotiation that costs more than $\$ 30$ will not be undertaken by the organic farmer.

Note here that the GMO farmer was induced by the liability rule to change its behavior without having to transact with the organic farmer. In other words, the efficient joint production of $\$ 170$ was obtained 
without a transaction at all. This was not true on the parallel facts of Scenario 2.I, where the organic farmer had to negotiate with the GMO farmer to switch to a non-GMO seed. In other words, in a world with sufficiently high transaction costs, the value of joint production may be different in Scenario 2.I (\$170 with no transaction costs but $\$$ I 40 with significant transaction costs) and Scenario 3.I (\$I70 regardless of transaction costs). Clearly, the assumption of zero transaction costs is essential to the proposition that the choice of liability or no liability is irrelevant to net social welfare. When transaction costs are accounted for, the choice of a rule of liability or no liability may well affect social welfare.

Finally, it is worth considering one more permutation within the liability scenario. If switching costs were sufficiently low, the GMO farming firm might be induced to change its practices entirely and become an organic farmer, which would mean not only foregoing GMO seeds, but also not using chemical herbicides, pesticides, and fertilizers. In the unlikely case where switching costs are zero for the GMO firm, the joint production in subsequent years might rise to $\$ 200$, as illustrated below:

Scenario 3.2: LIABILITY + ZERo SwITCHING COSTS

EX-GMO FARMER

Organic Farmer

Io Acres/30 Bushels

ro Acres/3o Bushels

$(\$ 4 /$ bushel $x$ 30) $-\$ 20$ C.O.P. $=\$ 100$

JoINT ProDuCnoN $=\$ 200$

\$4/bushel $\left.x_{30}\right)-\$ 20$ C.O.P. $=\$ 100$

To summarize, under a regime of liability for pollen contamination, the joint value of corn produced will be $\$ 140, \$ 170$, or $\$ 200$, depending on how costly it is for the GMO farmer to switch from GMO farming to alternative farming techniques.

\section{Conclusions}

First, the magnitude of switching costs will affect the value of joint corn production between the neighbors, but the choice of liability or no liability has no effect on net corn production, which will always be $\$ 140$, $\$ 170$, or $\$ 200$ given the assumed level of switching costs. In other words, although each farmer may care deeply about which rule is adopted, the

35. Coase emphasizes this point. See Const, supra note 2, at IIS (noting that when transaction costs are taken into account, "the initial delimitation of legal rights does have an effect on the efficiency with which the economic system operates"). legal system arguably should not because the net corn production under either legal regime is the same. Second, as seen in the comparison of Scenarios 2.I and 3.I, the assumption of zero transaction costs is critical to the validity of the first conclusion. Both of those scenarios were based on identical factual assumptions, but in a world of high transaction costs, we saw a $\$ 30$ difference in net social welfare (\$r70 as compared to \$140) depending on the liability rule adopted. We shall explore the world of transaction costs in more detail below. This is how the Coase Theorem works in a nutshell: in a world with no transaction costs, there seems to be no economic reason to impose liability on the pollen polluter. The tax on harm caused by neighbors suggested by Pigou is not justified. ${ }^{3 / 4}$

We must note that we have not only ignored transaction costs, but also third party wealth effects. The choice of liability rules may affect parties outside the two-player paradigm employed above. A rule of no liability, for example, might force most organic farmers to switch to GMO farming, resulting in crop monocultures that are vulnerable to catastrophic failure or that threaten genetic or ecological diversity. A rule of liability for pollen drift, on the other hand, might affect the net income of firms that sell patented GMO seeds. We consider these sorts of externalities in Part I.D below.

\section{B. Pollen Drift in a World with High Transaction Costs}

To quote Professor Coase, a world without transaction costs "is, of course, a very unrealistic assumption." ${ }^{37}$ It is often very costly for parties to come to an agreement, and in the case of pollen drift, it may be very difficult for the victim of airborne contamination to even identify the proper part(ies) with whom to negotiate. In the case of a crop like corn, which casts its pollen for miles, ${ }^{35}$ it may be impossible for an organic farmer to identify and bring to the table all the possible GMO farming firms that might be the cause of contamination. It is no surprise that Coase himself uses airborne pollution as an example of a nuisance which raises the specter of prohibitively high transaction costs. He describes the number of the parties potentially affected by a belching smokestack and notes that the airborne pollutants would "affect a vast number of people engaged in a wide variety of activities." transacting is "often extremely costly, sufficiently costly at any rate to prevent many transactions that would be carried out in a world in which

\footnotetext{
36. See Pigou, supra note 4.

37. Const, supra note 2 , at 114

8. See infra notes $83-87$ and acompanying text.

39. Conse, supra note 2, at 117 .
} 
the pricing system worked without cost."

As we explain in the previous Part, when transacting is costly, as it is very likely to be in the pollen drift context, the choice of liability rules may affect social welfare. For this reason Coase argues that "[o]nce the costs of carrying out market transactions are taken into account ... the initial delimitation of legal rights does have an effect on the efficiency with which the economic system operates." ${ }^{11}$ When transactions are costless, neighbors can negotiate around whatever liability rule is imposed on them. The rule will affect the distribution of wealth between the parties, but net social welfare will remain the same. When transacting is costly, we must be careful in advocating one rule over another, because the parties may not be able to adjust to maximize their joint production. This is the primary corollary of the Coase Theorem. As Coase warns, unless the efficient arrangement of rights is that "established by the legal system, the costs of reaching the same [efficient] result by altering and combining rights through the market may be so great that this optimal arrangement of rights, and the greater value of production which it would bring, may never be achieved." ${ }^{42}$ We see how this corollary plays out in the illustrations below and then apply the framework to the specific question of what legal rules should govern the problem of pollen drift.

\section{Assigning Rights in Context}

Depending on the individual facts of a particular pollen drift case, society should sometimes prefer a rule of liability for contamination and other times prefer a rule of no liability. Take, for example, the fact situation discussed above in Scenarios 2.I and 3.I. In both those hypotheticals, the organic farming firm would suffer a $\$ 60$ loss if its crop were contaminated by a neighbor's GMO pollen. We assume now that the cost of negotiating an agreement for the organic farmer to pay the polluter $\$ 30$ to switch to an alternative non-GMO seed would be too high, given the practicalities of meeting, negotiating, drafting, inspecting, and monitoring the agreement. In addition, the distance that corn pollen travels will make it very difficult for the organic farmer to discover

\section{Id. at 114.}

In order to carry out a market transaction, it is necessary to discover who it is that one
wishes to deal with, to inform people that one wishes to deal negotiations leading up to a beople that one wishes to deal and on what terms, to conduct negotiations leading up to a bargain, to draw up the contract, to undertake the inspection

Id.

41. Id. at 115

42. $I d$. beforehand whose pollen will cause the contamination. Or, more than one GMO farmer may be nearby, which complicates negotiations. If transaction costs are sufficiently high and there is no liability for the contamination, then the value of the joint corn production would be $\$ \mathrm{I} 40$, as illustrated below:

\section{Scenario 4.o: No LIABILITY}

GMO FARMER

to Acres/10o Bushels

ORGANIC FARMER

$(\$ 2 /$ bushel $x 100)-\$ 100$ C.O.P. $=\$ 100 \quad\left(\$ 2 /\right.$ bushel $\left.x_{30}\right)-\$ 20$ C.O.P. $=\$ 40$

JoINT PRODUCnON $=\$ 140$

If, however, we impose liability on the GMO farmer for damage done to the organic farmer, then the GMO farming firm will have a monetary incentive to switch to the alternative non-GMO seed. If it does, then the value of joint production rises to $\$ 170$, as illustrated below:

\section{Scenario 4.I: LIABILITY}

\section{GMO FARMER}

Io Acres/8o Bushels

Organic Farmer

(\$2/bushel x 80) - \$90 C.O.P. $=\$ 70$

JoINT PRODUCTION $=\$ 170$

On these facts, it is clear that society should prefer a rule of liability for the contamination because net welfare will be higher. As we see below, however, it would be improper to generalize from this result. As Coase suggests, a different context may require a different assignment of rights.

For example, consider the following example that accounts for the fact that soybean pollen does not travel nearly as far as corn pollen. ${ }^{43}$ We offer the case of an organic soybean farming firm that produces thirty bushels of beans on ten acres after expending $\$ 20$ in production costs and receives $\$ 4$ per bushel for its crop before a GMO soybean enterprise begins farming on a neighboring field. The GMO farming firm also plants ten acres. It produces one hundred bushels after expending $\$ 100$ in production costs, for which it receives $\$ 2$ per bushel. If GMO pollen contaminates the organic farming firm, it will lose $\$ 60$ in profits. The contamination could be averted if the GMO farmer switches to an

43. See infra notes $83-90$ and acompanying text. 
alternative seed. If the GMO firm switches, it will produce twenty fewer bushels, save \$10 in its cost of production, and receive \$30 less in income. Because soybean pollen does not travel nearly as far as corn pollen, the contamination could be averted if the organic farmer leaves fallow a tenfoot strip of land adjoining the GMO farmer's property. The cost to the organic farmer of leaving the strip of land fallow is \$20. If the GMO farmer is liable for the contamination, it will switch to the non-GMO corn and the value of the joint corn production will be $\$ 170$, as illustrated below:

\section{Scenario 5.O: LiABILITY}

\section{GMO FARMER}

Io Acres/8o Bushels

ORGANIC FARMER

(\$2/bushel $\times 80)-\$ 90$ C.O.P. $=\$ 70$

JoINT ProDuction $=\$ 170$

Io Acres/30 Bushels

$\left(\$ 4 /\right.$ bushel $\left.x_{30}\right)-\$ 20$ C.O.P. $=\$ 100$

If the GMO farming firm is not liable, then it has no incentive to switch to non-GMO seeds and it will produce a crop worth \$roo. The organic farmer, worried about damage caused by contamination, will leave fallow a ten-foot strip of land at a cost of $\$ 20$, dropping the value of its production to $\$ 80$. Note that joint production in this case rises to $\$ I 80$, as illustrated below:

\section{Scenario 5.I: No LIABILITY}

\section{GMO FARME}

Io Acres/8o Bushels

$(\$ 2 /$ bushel $\times 100)-\$ 100$ C.O.P. $=\$ 100$
ORGANIC FARMER

10 Acres/30 Bushels

$(\$ 4 /$ bushel $\times 30)-\$ 20$ C.O.P. $-\$ 20=\$ 80$
JoINT PRODUCTION $=\$ 180$

Under the facts of our soybean hypothetical, joint production is maximized by the adoption of a rule of non-liability. Unlike in our corn example, net social welfare is maximized if the GMO farmer is not held liable for pollen drift contamination.

In a world without transaction costs, the choice of rules would not matter. In Scenario 4.0 (no liability), the organic farmer would pay the GMO farmer to switch to a non-GMO seed and then joint production would be the same as in Scenario 4.I (liability). In Scenario 5.0 (liability), the GMO farmer would pay the organic farmer to leave a strip of land fallow and joint production would be the same as in Scenario 5.I (no liability). In the real world of high transaction costs, however, the choice of rules will have a significant effect on net social welfare. Sometimes it makes economic sense to hold neighbors liable for contamination caused by drifting pollen; sometimes it does not. As Coase explains, "[w]hether [a liability rule] is desirable or not depends on the particular circumstances,"

\section{ImPLicATIONS For COMmon LAw AdJudicATION}

Coase discusses at length many common law cases involving neighbors who do harm to each other. ${ }^{45}$ Consistent with his theoretical analysis, when transaction costs must be accounted for, the criterion of efficiency justifies liability in some cases but not in others. ${ }^{46}$ Indeed, a case-by-case analysis of problems involving neighbors seems to be the only feasible approach, considering the numerous facts necessary to making the proper decisions. In the scenarios set forth above we had to examine farming methods, typical crop yields, costs of production, market values, the availability of alternative seeds and protective measures, and the magnitude of each farmer's switching costs. The change in a single factor, for example from corn to soybeans, can generate a different optimal arrangement of rights between the two parties.

We suggest, therefore, that any common law method of adjudication that is sensitive to the relevant factors identified above has the potential to establish efficient rules for liability or non-liability. We will discuss in Part III below whether the nuisance, trespass, and strict liability doctrines employed by the American law of neighbors are up to the task, but first we must apply the Coasean framework to the complex questions raised when the patentee of the GMO product claims to have suffered harm that deserves recompense. Discussing patent law is important, because if patent law imposes liability on bystanding farmers, then their costs of production will rise and the equilibria described above will be upset. If those equilibria represent efficient results, then measuring the intrusion of patent law into the game becomes critically important.

\section{Implications for Patent LaW}

Many GMO seeds and the pollen that GMO plants produce are patented. ${ }^{67}$ So far, we have ignored the interests of patentees claiming a

4. ConsE, supra note 2, at 141

45. Id. at $105-14,121-31$.

46. See id. at $13 \mathrm{I}$ ("It is all a question of weighing up the gains that would accrue from eliminating these harmful effects against the gains that accrue from allowing them to continue."

47. See J.E.M. AG Supply, Inc. v. Pioneer High-Bred Int'1 Inc., 534 U.S. 125, 141 (2001); see, e.g., 
property right in genetic material cast to the wind. ${ }^{4^{5}}$ Unless the GMO farm is owned by a biotech research firm like Monsanto, it is unlikely that the GMO farmer will also be the owner of the patent on the GMO seed, plant, and pollen. Therefore, the possible claims of a third party, the patentee, must be considered.

Patent law gives the patent owner the exclusive right to use, make, sell, offer to sell, and import the invention subject to the patent. ${ }^{9}$ Patent law is based on notions of strict liability; neither the infringer's knowledge, nor her intent, is relevant. ${ }^{50}$ Patent law does not excuse unwitting or inadvertent infringement. A brief look at U.S. Patent No. 6,1 I4,610, owned by Monsanto Corporation, demonstrates the plausibility of the claim that even a bystanding farmer should be liable:

[The patent] relates to the seeds of inbred corn line $\mathrm{ASG}_{27}$, to the plants of inbred corn line ASG 27 and to methods for producing a corn plant produced by crossing the inbred line ASG27 with itself or another corn line [and] to hybrid corn seeds and plants produced by crossing the inbred line ASG 27 with another corn line.

In addition to claiming the plant, ${ }^{52}$ its seeds ${ }^{53}$ hybrid plants, ${ }^{54}$ and hybrid seeds, ${ }^{55}$ the patent covers the pollen of the plant, ${ }^{56}$ the method for crossbreeding a hybrid, ${ }^{57}$ and various gene conversions ${ }^{8 /}$ of the patented plant.

Given the broad scope of Monsanto's claims, it is relatively easy to see how a bystanding farmer could unwittingly violate the patentee's statutory rights. If the wind blows the patented pollen onto a bystanding farmer's corn plants and those plants are pollinated, then the farmer has arguably used the pollen in violation of the Monsanto patent. The

the seed corn patent described infra notes $5 \mathrm{I}-58$ and acompanying text.

48. As long as the bystander affected by pollen drift views the genetically modified organism as harmful contamination, this seems appropriate. In the case of an organic farmer who does not want the genetic material, then the patent owner has not been damaged by losing a potential sale. A recipient of pollen drift might be a beneficiary, however, if it welcomed the new genetic material. This was allegedly the case in Monsanto Canada, Inc. v. Schmeiser, [2004] I S.C.R. 902 (Can.), where Monsanto claimed the farmer took deliberate advantage of Round-Up Ready plants that were pesticide resistant. Id. at 936 .

4. See 35 U.S.C. 5271 (a) (2003).

50. See Hilton Davis Chem. Co. v. Warner-Jenkinson Co., 62 F.3d 1512, 1527 (Fed. Cir. 1995) Infringement is ... a strict liability offense."), rev'd on odher grounds, 520 U.S. 17 (1997).

51. U.S. Patent No. 6,114,610 (filed Dec. 8, 1998).

52. Id. at col.nI L.55.

53. Id. at col.ri ll. $52-54$.

54. Id. at col.r. 1 ll. $23-24$

55. Id. at col.12 1.22

56. Id. at col.ri 1.57.

57. Id. at col.12 ll.16-21

58. Id. at col. 12 ll. $34-60$ pollinated plants would then produce hybrid seeds in potential violation of Monsanto's method patent for hybridization and its product patent for hybrid seeds. If the plants are harvested and the hybrid seed sold, a further violation of Monsanto's right to sell the patented seeds may occur. Any infringement of the patent gives its owner the right to injunctive relief, which most importantly includes enjoining the sale of the harvested crops. ${ }^{9}$ Patent owners may also recover damages or a reasonable royalty for the infringement. ${ }^{60}$

Although the legal argument for infringement liability is plausible, the Coasean analysis conducted above suggests that a liability rule of uniform applicability is not justified economically. Remember that the primary argument in The Problem of Social Cost is against the automatic levying of a Pigovian tax (a real tax or the imposition of legal liability) on a firm that causes harm to another. ${ }^{6 t}$ As we have seen, it often makes economic sense to allow one firm to engage in an activity that harms another without forcing that firm to internalize its costs. For example, in Scenario 5.I, net social welfare was maximized by a rule of no liability for a GMO soybean farmer. Once we account for transaction costs, optimizing social welfare will sometimes demand a liability rule and sometimes not. It follows that the automatic levying of a Pigovian tax on the passive recipient of pollen drift cannot be justified, and therefore, liability for bystanding farmers in all cases cannot be justified.

\section{Farmers Benefiting from Pollen Drift}

According to Coase, if transaction costs are high, then different contexts should demand differing liability approaches. ${ }^{\text {ta }}$ Consider Farmer $A$ who plants ten acres with herbicide-resistant GMO canola seed. After expending $\$$ Ioo on operating costs (seed, pesticides, and herbicides) he will harvest one hundred bushels which he can sell for \$2 per bushel. His $\$$ IOo in operating costs includes a royalty payment to Patentee, who invented the herbicide-resistant seed. A neighbor, Farmer $B$, plants ten acres with cheaper non-GMO seed. In year one, after expending \$go for seed, pesticides, and herbicides, he will harvest eightyfive bushels of corn which he can sell for $\$ 2$ per bushel. During the growing season, pollen from Farmer $A$ 's GMO canola fertilizes Farmer $B$ 's canola. After the harvest, Farmer $B$ saves enough hybrid seed to plant the following year. In year two, after expending only $\$ 80$ for

35 U.S.C. $5.271(e)(4)(B)(2003)$

60. Id. \$ $271(\mathrm{e})(4)(\mathrm{C})$.

6r. COASE, supra note 2, at $180-84$.

62. Id. at 178 
pesticide and herbicides, Farmer $B$ harvests one hundred bushels that he can sell for $\$ 2$ per bushel. In year two, Farmer $A$ makes the same $\$ 100$ profit that he made in year one, while Farmer $B$ makes $\$$ I 20 . Farmer $A$ 's $\$$ roo operating costs include a $\$ 20$ royalty payment to Patentee. In developing the seed, Patentee's research and development costs allocable to year two were $\$ 35$. If Farmer $B$ is not liable for patent infringement to Patentee, then the value of joint production of Farmer $A$, Farmer $B$, and Patentee is $\$ 205$, as illustrated below:

\section{Scenario 6.o: No LiabILITY}

FARMer $A$

to Acres/10o Bushels

FARMER $B$

$(\$ 2 /$ bushel $x 100)-\$ 100$ C.O.P. $=\$ 100$

10 Acres/100 Bushels

$(\$ 2 /$ bushel $x$ 100 $)-\$ 80$ C.O.P. $=\$ 120$

Patentee

$\$ 20$ Royalty Payment $-\$ 35$ Research and Development Costs $=(-\$ 15)$

\section{JoINT PRODUCTION $=\$ 205$}

Note that imposing liability for patent infringement will not change the value of the joint production of the three parties.

\section{Scenario 6. I: LIABILITY}

FARMer $A$

10 Acres/10o Bushels

$(\$ 2 /$ bushel $x$ roo $)-\$ 100$ C.O.P $=\$ 100$

\section{FARMer $B$}

Io Acres/10o Bushels

(\$2/bushel x IO0) - \$80 C.O.P. - \$20 damages $=\$ 100$

\section{PAtentee}

\$20 Royalty Payment + \$20 Damage Award

$\$ 40-\$ 35$ Research and Development Costs $=\$ 5$

\section{JoINT Production $=\$ 205$}

At first glance, there seems little reason to require a transfer payment from Farmer $B$ to Patentee. If joint production is not increased, a deadweight loss is created by requiring a sterile transfer. Nonetheless, even though the imposition of liability for infringement does not increase the net value of the joint production, a plausible economic argument can be made that unless Patentee can recover its research and development costs by collecting royalties for the use of its invention, it will have inadequate incentives to invent the herbicide-resistant seed. This sort of negative externality is relevant to Coasean analysis, and the hypothetical is designed to accentuate this point. If the seed company knows that it cannot collect a second royalty, its research and development costs $(\$ 35)$ will exceed its expected return ( $\$ 20$ from Farmer $A$ ), and it may not invent the seed. This externality is "harm" in the sense Coase uses the term. ${ }^{63}$ Without the herbicide-resistant seed, both farmers will be forced to use the non-GMO seed planted by Farmer $B$ initially, and Patentee will save the $\$ 35$ expended on research and development. The value of joint production will fall to $\$$ I 95 without the availability of the GMO seed, as illustrated below:

Scenario 6.2: GMO SEED NEVER INVENTED

FARMER $A$

FARMER $B$

10 Acres $/ 85$ Bushels $\quad$ Io Acres $/ 85$ Bushels

$(\$ 2 /$ bushel $x 85)-\$ 90$ C.O.P. $=\$ 80 \quad(\$ 2 /$ bushel $x 85)-\$ 90$ C.O.P. $=\$ 80$

PATENTEE

No Royalty Payments

Research and Development Costs Saved $=\$ 35$

JoINT Production $=\$ 195$

A comparison of Scenarios 6.I and 6.2 seems to make a strong case for liability. Forcing the transfer payment will stimulate production of the herbicide-resistant seed, which will in turn increase the net value of corn production by $\$ 10$, to $\$ 205$. It appears that net social welfare is increased. Scenario 6.2 assumes, however, that Patentee will not do anything socially useful with the $\$ 35$ research and development expenditure that it has saved. This is a highly unrealistic assumption. If those savings can be invested to produce value that exceeds the $\$ 20$ corn production gain, then society should prefer that the herbicide-resistant seed not be invented. This question of marginal utility pinpoints one reason why economists are so hesitant to argue that patent law is efficient; it is extremely difficult to account for the alternative uses to which inventive resources might be put..$^{64}$

63. See supra notes 26-29 and accompanying text.

64. See also Paul J. Heald, The Vices of Originality, 1991 SuP. Cr. Rev. 143, 157 n.69 (1991) ("In 
The argument in favor of liability, therefore, is linked to the assertion that patent law provides efficient incentives to invent. It certainly does in our hypothetical, but the matter is far from undisputed. ${ }^{65}$ We could easily change the facts so that the incentive effect is missing. ${ }^{66}$ Nonetheless, at least in some cases, one can argue that the negative externality caused by the bystanding farmer's use without compensation should be internalized in the form of a rule requiring a transfer payment to the patentee.

By re-characterizing the fact situation as presenting a positive externality (higher corn production for Farmer $B$ ) generated by the inventive effort of the Patentee, a similar argument can be offered why Farmer $B$ should be liable. Demsetz has argued that systems of private property are more efficient than systems of common property. ${ }^{67}$ If we let Farmer $B$ benefit from Patentee's inventive efforts without paying, then we are treating the herbicide-resistant genetic material as common property. Liability would privatize the genetic material and allow the inventor of the herbicide-resistant seed to recover the benefit conferred on Farmer $B$. According to Demsetzian analysis, forcing a transfer payment from Farmer $B$ in the amount of the benefit will arguably

other words, a work should be [patentable] only if necessary to encourage the work and the work is more socially useful than whatever else the [inventor] would choose to do, for example, child rearing or brickmasonry."); cf. RICHARD A. POSNER, ECONOMIC ANALYSIS of LAw 37 (3d ed. I986) ("The costs of the patent system include ... inducing potentially exoessive investment in inventing."); Janusz A. Ordover, Economic Foundations and Considerations in Protecting Industrial and Intellecrual Propery, 53 ANTmiust L.J. 503, 507 (1985) ("[Patent law] may lead to excessive investment in the fs of intellectual and industrial property."

65. See Paul J. Heald, A Transaction Costs Theory of Patent Law, 66 Oнно St. L.J. 473.499 (2005) (discussing "empirical studies demonstrating... the poor correlation between R\&D and patenting shown in recent studies on the impact of the Federal Circuit on the behavior of inventive firms .... and the prevalence of patenting despite low levels of licensing, use, and highly uncertain prospects for super-competitive profits ...."); see also id. at 499-506 (collecting studies critical of incentive theory of patent law). For the most famous statement of skepticism, see S. Comm. on the JuDiciarY, 8 5TH Cong., An Economec Review of the Patent System: Study No. is of the Sumcoms. on Patents, Trademarks, AND Copyeghts 80 (Comm. Print 1958) (reporting Fritz Machlup's study):

If we did not have a patent system, it would be irresponsible, on the basis of our present knowledge of its economic consequences, to recommend instituting one. But since we have had a patent system for a long time, it would be irresponsible, on the basis of our present

66. For example, if the inventor's research and development costs are $\$ 50$, and the two farmers constituting the entire potential market for the seed would not be willing to pay more than a $\$ 20$ royalty each, a liability rule will not stimulate the invention of the new seed. Or, if the inventor is himself a tarmer who can make a substantial profit over his R\&D costs by inventing the new seed, then making other farmers liable provides no added incentive. The seed would be invented even in the absence of liability.

67. See generally Harold Demsetz, Toward a Theory of Property Rights, 57 AM. Econ. Rev Partrs \& Pæóc. 347 (1967). optimize social welfare. ${ }^{68}$ In Demsetz's view, the value of the additional corn that Farmer $B$ harvests in year two is a positive externality created by Patentee's inventive efforts that should be captured by Patentee. Professor Frischman describes Demsetz's normative thesis as arguing that "the emergence of private property rights to enable the internalization of externalities is desirable (in an economic framework, social welfare maximizing), ${ }^{, 69}$ It is hotly disputed whether Demsetz's theory of property should be extended to spillovers created by intangible public goods like inventions, ${ }^{70}$ but his approach does provide another argument in favor of liability.

Coase and Demsetz really present two sides of the same coin. Externalities, whether described as positive or negative, get treated the same way by economists. One can argue that the infringing farmer should internalize the negative effect its behavior has on research and development incentives, or one can argue that the patentee should internalize the positive effect its inventiveness has on the infringing farmer. In either case, liability is premised on the notion that the patentee will make a sub-optimal investment in research and development expenditures. If patent law has a significant incentive effect on research and development expenditures and those expenditures are not wasted, then a plausible argument can be made that a benefiting bystanding farmer should have to make a transfer payment to the patentee.

\section{Farmers Harmed by Pollen Drift}

Although forcing the transfer payment of $\$ 20$ from Farmer $B$ to Patentee in the above scenario may be justified as the recovery of a benefit conferred on Farmer $B$ by the inventive efforts of Patentee, the same cannot be said in the case of the organic farmer who is harmed by pollen drift. In such a case, there is no benefit conferred and the economic justification for the transfer payment is missing. A transfer

68. Id.

69. Brett M. Frischmann, Evaluating the Densetzian Trend in Copyright Law, 2 Rev. L. \& EcoN. (forthcoming 2006) (manuscript at 2, on file with author); see also Richard A. Epstein, The Allocation of the Commons: Parking on Public Roads, 3t J. Leani. Srup. 515, 515-16 (2002) ("Demsetz argued that ... systems of private property generally outperform systems of common property, because when individuals internalize both the costs and benefits of their decisions they are more likely to advance the social interest .....")

70. See Frischmann, supra note 69, at 3-5; see also Brett M. Frischmann, An Economic Theory of Infrastructure and Commons Managemem, 89 MinN. L. REv. 917, 997-98 (2005); Mark A. Lemley. Propenty, Intellectual Property, and Free Riding, 83 TEx. L. Rev, I031, 1072 (2005); Brett M. Frischmann \& Mark A. Lemley, Spillovers I (Stanford Law Sch. John M. Olin Program in Law and Econ., Working Paper No. 321, 2006), available at http://ssm. $00 m /$ abstract=89888 
payment would be sterile, imposing a deadweight loss on society.

Imposing liability on opportunistic farmers who benefit from pollen drift is based on contested assumptions about the incentive effects of patent law and the desirability of internalizing the positive wealth effects of production. Both of these theories are premised on the notion that a patentee should be able to capture the benefits generated by the invention. In the case of the organic farmer, the invention confers no benefit; in fact, it imposes a cost. Imposing liability in the case of a bystanding non-GMO farmer would constitute a reverse Pigovian tax, forcing someone who has suffered a harm to make a transfer payment to the party who caused the injury. There is no positive externality to be internalized. Both theories also presume that liability takes the place of voluntary transactions that would have been entered into in the market. For example, given his expected benefit, Farmer $B$ should have been willing to pay up to $\$ 20$ for the use of the herbicide-resistant seed in our prior scenario. The farmer behaved opportunistically and avoided the payment, but imposing liability would mimic the sort of transaction that normally occurs on the market-just look at how Farmer $A$ behaved. In the case of the organic farmer, however, imposing liability would not mimic a transaction that would otherwise be entered into. The farmer does not want to use the invention. In fact, the organic farmer is willing in Scenario 2.I to pay to avoid having to use the GMO product.

We conclude, therefore, that there is no economic justification for imposing liability on a bystanding farmer who is harmed by pollen drift, while we concluded earlier that an opportunistic farmer who takes advantage of wind-blown genetic material should be liable. This is consistent with Coasean analysis which suggests that "[w]hether [a liability rule] is desirable or not depends on the particular circumstances." ${ }^{\prime 71}$ In addition, we note that the equilibria between the neighboring farmers described above remains constant. Where the bystanding farmer is harmed, patent law plays no role. From the standpoint of the opportunistic beneficiary, there is no harm between the neighbors to complain of, and the scenario falls outside the two-neighbor nuisance model that we describe.

\section{GMO Crop Patents ANd Non-GMO MARKetS}

In Parts III and IV we examine the common law and statutory rules that govern the problem of pollen drift. In order to understand the importance of getting both the economics and the law correct, we will

\footnotetext{
7I. COASE, supra note 2, at $14 \mathrm{I}$.
}

briefly examine the technology relevant to the problem and take a snapshot of the potentially affected markets.

\section{A. GMO CRops}

The technology that produces GMO crops works to alter certain traits of the plant, such as size, color, lifespan, and resistance to certain pests or chemicals. Scientists begin by isolating the gene that produces the particular trait. Then, the isolated gene is integrated in the new plant, and the plant begins producing proteins that control the desired trait. Thus, if a plant has been genetically modified, successive generations will begin to exhibit the trait that the scientists desired it to have. ${ }^{72}$ As scientists have developed GMO crops in recent years, and those same crops have begun to find their way to the world market for food, the issues surrounding GMO crops have heated up. On one side are biotech companies and other advocates of GMO crop technology, who tout the benefits of increased yields and convenience. For example, because herbicides do not discriminate-that is, they will kill weeds and surrounding crops-spraying Roundup or other herbicides is a delicate and time-consuming practice. ${ }^{3}$ Herbicide-resistant crops, like Monsanto's Roundup Ready series, can save farmers time and money because the farmer does not have to spray carefully around his crops. ${ }^{74}$ In addition, plants that are genetically modified to repel insects save farmers from having to spray crops with expensive insecticides. ${ }^{\text {?s }}$

Beyond the basic convenience of GMO crops, advocates boast that GMO crops have the potential to be a major factor in alleviating some of the world's hunger. GMO crops might be created to grow larger and faster and have more vitamins and minerals. ${ }^{76}$ In developing countries with severe food shortages and populations suffering from malnutrition, these characteristics of GMO crops could arguably effect beneficial change. ${ }^{\text {.7 }}$

GMO crops, despite their claimed advantages, do have significant opposition. Critics cite the many risks of GMO crops: human allergies, plant resistance to pesticides and antibiotics, and the general loss of

72. For a brief summary of the science behind GMO crops, see Gabrielle J. Persley \& James N, Siedow, Applications of Biotechnology to Crops: Benefits and Risks, in Gevenically Modfied Foods 222-25 (Michael Ruse \& David Castle eds, 2002).

73. Flood, supra note 7 , at $477-7^{8}$.

74 Id.

75. 1d. 74.96

77. Id. at 479 . 
biodiversity ${ }^{78}$ There are also environmental risks to consider. Some warn that the insecticide-ready GMO crops could actually increase the population of harmful insects and could create "superbugs." Likewise, some scientists worry that herbicide-ready GMO crops could contaminate the surrounding weeds, creating "uncontrollable "superweeds.",

The potential human health risks of GMOs have also been debated One possibility is that people may develop allergic reactions to certain GMO food products that contain foreign materials, for example, from products like corn or beans that have been modified with peanuts or Brazil nuts. ${ }^{81}$ Critics' concerns are magnified by the fact that GMO foods do not currently have to be labeled in this country; thus. American consumers are often not warned that they are ingesting a product that may produce a harmful allergic reaction. ${ }^{82}$ Beyond these immediate concerns lies what is perhaps the most controversial aspect of GMO crops - the unknown. The technology employed to produce GMOs may be too new to provide reliable information about the long-term effects of crop usage. ${ }^{s_{3}}$ Although regulators have deemed biotech crops safe for the time being, opponents are concerned that there simply is not enough information to back that conclusion.

Despite strong opposition, biotech crops have managed to secure a large part of the domestic market for crops and crop commodities. There are currently four main GMO crops utilized in the United States: soy, cotton, corn, and canola. ${ }^{84}$ In 2004, GMO crops made up $85 \%$ of the United States soy acreage, $45 \%$ of the corn acreage, $76 \%$ of the cotton acreage, and $84 \%$ of the canola acreage. ${ }^{{ }^{5}}$

Interestingly, corn pollen poses special problems because it is especially susceptible to pollen drift. Spherical corn pollen particles are much larger than pollen produced by other plants, allowing them to travel farther on the breeze. ${ }^{86}$ Pollen from corn also finds its way to the

78. See Preston, supra note 21, at $1153-54$ (describing opposition to GMO crops).

79. Flood, supra note 7, at 480 .

8a. Id. at $479-80$.

81. DeGeer, supna note 21, at 272. In 1996, Pioneer Hi-Bred developed a GMO soybean containing a Brazil nut gene, which increased protein content. Id. The GMO soybean thus exhibited the allergen qualities of the Brazil nut, qualities that may be fatal in allergic humans. Id

82. Id

83. See Repp, supra note 9, at 587 (long term studies regarding the impact of GMO products are unavailable).

8. See Crr. For Food SAFETY, supra note 8, at 8

85. Id. at 8-9.

86. Tim Van Pelt, Note, Is Changing Patent Infringement Liability the Appropriate Mechanism for ground at a rate of about one foot per second, much faster than other types of pollen. ${ }^{57}$ A single corn plant produces between four and five million particles of pollen. If even a small amount of a cornfield's pollen drifts to nearby fields, the potential for cross-pollination can be quite serious. ${ }^{59}$ Corn has been described by one scientist as "basically just broadcasting piles of pollen out into the air and hoping it lands where it's needed." $\$$

For other crops, a relatively small buffer zone between GMO and non-GMO crops may be effective to prevent unwanted pollinization. Corn pollen, however, travels much farther distances, making buffer zones costly, if not economically unfeasible altogether. One buyer of organic corn seed reports that some of his growers have chosen urban environments, like Chicago, as the safest places to grow without the risk of contamination. ${ }^{\text {t }}$

In 2000 , pollen drift was one of the factors leading to the spread of StarLink corn, a genetically modified corn approved only for animal consumption." StarLink was planted on less than $1 \%$ of the United States corn acreage in 2000 , but appeared in $10 \%$ of the crop harvested that same year., The discovery of StarLink in human food sources led to massive recalls of food products and plummeting export sales. ${ }^{94}$ Although one cause of the StarLink crisis was improper handling of the crops, experts say that pollen drift compounded the problem. ${ }^{95}$

\section{B. The Market for Non-GMO Food Products}

Were it not for the growing importance of world markets for nonGMO food products, the problems posed by pollen drift might not be so acute. Defining the size of the market for non-GMO products is complicated by the fact that no international agency keeps direct statistics. In most cases, the market for organic products has to serve as a

Allocening the Cost of Pollen Drift?, 31 J. Conp. L. 567.587 N.159 (2006),

87. Peter Thomison, Managing "Pollen Driff" to Minimize Contamination of Non-GMO Corn,

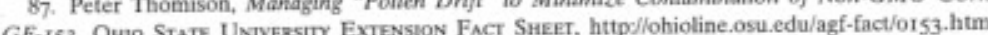
(last visited Sept. 30, 2006).

88. $I$.

89. Id. Fon

90. Anne Fitzgerald, Specially Poulen Concerns 1. Glenn Roberts, Founder, Anson Mills, President Address at Seeds of Resistance/Seeds of Hope Conference (Apr. 8, 2004).

92. See Fitzgerald, supra note 90

93. Id.

94. $1 d$

95. Id. 
proxy because, by most current definitions, organic products cannot contain genetically modified materials. ${ }^{96}$ Counting only sales of organic products, however, significantly undercounts the size of non-GMO markets around the world, because many non-GMO farmers are not organic farmers. Japan, for example, places restrictions on GMO food products, but it does not demand that farmers grow organically. Farmers who want to satisfy the huge demand for non-GMO soybeans and soybean oil in Japan, ${ }^{n}$ for example, or who wish to sell in a variety of product markets in the European Union where many GMO goods are banned, may use synthetic pesticides, herbicides, or fertilizers to grow their crops. A look at the growing worldwide market for organic goods can at least set a baseline. A 2004 survey reveals that 24,070,0Io hectares are currently under organic cultivation around the world. ${ }^{98}$ In 2002, the global market for organic food products topped $\$ 23$ billion $^{99}$ and was growing at a rapid rate, between $8-12 \%$ per year in Europe and North America. ${ }^{100}$ From 1992 to 1997 , certified organic acreage in the United States grew by $44 \%$ and organic cropland by iII \%. ${ }^{100}$ Over twelve thousand stores in the United States specialize in selling organic foods, but conventional supermarkets have begun to market organics to a significant extent. As of 2000 , over $42 \%$ of all organic foods were sold in chain supermarkets. ${ }^{103}$

The market for organic foods is growing at a rapid pace, but undoubtedly slower than the overall market for non-GMO goods. Considering EU and Japanese restrictions on GMO imports ${ }^{104}$ and the effect of labeling laws in those jurisdictions, ${ }^{105}$ farmers will have increasing incentives to avoid planting GMO crops. Even in the United

96. See Rudy Kortaech-Olesen, Int’l Trade Centre, United Natrons Conf. on Trade and Dev./Womld Trade Oxg., What is Oroanic Agzicul.tuxe?, bttp://www.intracen.org/mdsislides/ organiésldoo3.htm (last visited Sept. 30, 2006)

97. Ser generally Richard Moore, Preserving Soybean Biodiversity in Japan: Reconsidering GMO, Pesticide. Free, Low Input, and Organic, in SeEDs of Resistance'SEeds of Hope: Crossing Borderhs IN the Repatriation and In Situ Conservamon of Tradmonal. Plants (Virginia Nazarea \& Robert Rhoades eds., fortheoming 2006) (on file with author) ("U.S. soybean and product exports were \$8.0 billion in 2004 .... [to] Japan and Europe, where there is the most opposition to GMO products.").

98. See The World of Organic Agraculture: Statistics and Eserging Trends is thl.t (Helga Willer \& Minou Yussefi eds., 6th rev. ed. 2004).

99. See id. at 21 .

100. See id. at 22-23.

tor. INT'L. THADE CTR., Food \& AGric. ORG, OF THE UNTtED NATtons, supra note 7, at 209.

I02. Id.

104 See Repp, supra note 9, at $\$ 93$ (noting that the United States lost \$200 million annual export market for corn to the European Union over a two-year period).

Ios. Id.
States, the incentives are significant. A recent study reveals that in American supermarkets, the price premium for organic versus conventional fresh produce was from $11 \%$ to $121 \%{ }^{106}$ At one convention organic produce was $36.8 \%,{ }^{107}$ Pollen drift poses a significant threat to farmers who wish to take advantage of this price premium.

\section{THEORIES OF TORT RECOVERY FOR NON-GMO FARMERS}

Tort law is likely to grant significant relief to bystanding farmers who suffer harm when their crops are pollinated from GMO crops. The three primary theories are (1) private nuisance, ${ }^{\text {, }}{ }^{\circ}$ (2) strict liability, ${ }^{\text {tog }}$ and (3) trespass to land, ${ }^{110}$ and at least three other theories are possible: (4) public nuisance,"' (5) negligence," ${ }^{12}$ and (6) interference with personal

I06. INT'L TPADE CTR, FOOD \& AGRIC. ORG OF TIE UNITED NATIONs, supra note 7, at 215

107. $J d$.

108. Sce infra notes $\mathrm{I} 19-179$ and accompanying text.

109. See infra notes $180-235$ and accompanying text.

110. See infra notes $236-264$ and accompanying text.

III. Nuisance law distinguishes between public and private nuisances: a public nuisance affects the safety or health of members of the general public, while a private nuisance affects individuals or a group of individuals in some private way not felt by the public at large. Under public nuisance, the bystanding farmer must demonstrate an unreasonable interference with a right of the general public, bystanding farmer must demonstrate. an coupled with special harm to plaintil. harm is easy to satsly through 884, 884-85 (S.C. 1956) (finding special harm where obstruction of Gaffney Dev. Co, 92 S.E.2d $883,884-8$ ( roadway resulted in crop loss). The ar the risks or general annoyance to the community. See WuLuar The Prosea W. PACE Kremox, Prosser \& KeETON ON THE LaW OF TORTS \$ 90 (5th ed. 1984) (defining a L. Prosser a W. Ps "wath obstructs or causes inconvenience or damage to the public nuisance as public in the exerese of hog ranch); P. 191, 195 (Colo. Ct. App. .912) (Cosic State v. Chrisp, 85 N.C. 528,534 (188)

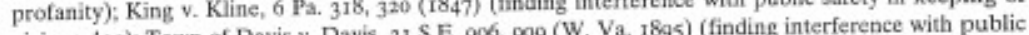
vicious dog), Town of Davs v. Davs, 21 s.E. go, gog (Wy peace in loud noise). If the GMO crops are approved by the gor her affected crops in a market for which they are not apposd, thene wion ap. S. Supp. ad 828 (ND.

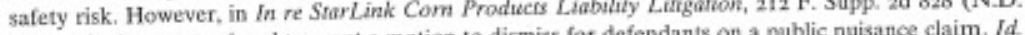
IIL. 2002), the court refused to grant a motion to dismiss for detendants on a public nusance claim. Id at Bs2. Plantiffs asserted that commingling of StarLink com after tarnesing tasd pottuted the entire U.S. corn supply. Id. at 833. The court considered the alleged contamination of tho generall food supply to be the public nuisanoe, not the damage to plaintiffs' individual crops. $I d$. at 848.

112. The negligence claims most likely to be asserted are a failure of the creator and seller of GMO seeds to warn their purchasers of the risk of injuring neighboring GMO farmers through cross pollination, and the failure of those parties and the GMO farmer to employ adequate buffer zones. On occasion, some courts tie negligence and private nuisance together, but they are analytically distinct. See When L Prosseg, HandpoOK OF THE LAw OF TokTs \& 71, at 553-57 (1941). Nuisance is at intentional 
property (trespass to goods or conversion). ${ }^{13}$ We focus on the primary theories sequentially although, as will become obvious, categories overlap, and doctrinal confusion as to the scope of the categories and their interrelationships is pervasive.

With respect to the substantive elements of the tort causes of action, it makes no difference whether the farmer is a plaintiff, or instead is a defendant asserting the action as a crossclaim or counterclaim in a patent infringement action brought by the owner of the patent on the neighboring GMO crops. For ease of description, we hereafter refer to the bystanding farmer as "plaintiff." In either type of case, the bystanding farmer must make a decision as to whom to sue. For all the tort claims, the logical defendant is the nearby landowner whose GMO crop has tainted the bystanding farmer's crop. Sometimes there will be multiple defendant landowners, and sometimes the sources of the GMO pollen will not be immediately obvious when the farmer discovers the injury. Expert evidence, including DNA analysis, ${ }^{14}$ may help to resolve causation issues. If tort liability for damages exists, multiple landowner defendants may be jointly and severally liable, or a court may apportion liability."

Neighboring GMO farmers are the primary defendants for all of the tort actions. Involvement of other parties, including the patent owner, as tort defendants is trickier. The bystanding farmer may assert that the patent owner is liable for damages. When the manufacturer or seller of patented seeds is someone other than the patent owner (as is often the case), the seed manufacturer or seller is another potential tort defendant. Compared to the primary defendants, different legal analysis applies with respect to these "secondary defendants" who are inventing, promoting, and marketing of GMO products. The patent owner and seed seller are likely to defend on the basis that they lose control of the seeds when they are delivered to purchasing farmers. ${ }^{116}$ They do not make decisions as to planting or cultivation of the crops, or the use of buffer zones near boundary lines. They are not aware of the farmers' local conditions, including wind patterns and the presence of nearby organic or other non-GMO farmers. Such defenses have

\section{closely resembles nuisance balancing. Compare id. $\$ 31$, at $169-74$ with id. 887 , at $629-30$}

113. See infra notes $260-264$ and accompanying text.

114. See infra note 252 and accompanying text.

115. If a bystanding farmer asserts a counterclaim in a patent infringement case, the GMO farmers will not be parties in the original action. The farmer may have to add one or more GMO farmers cross-defendants

116. See StarLink Com, 212 F. Supp. 2 at 845 . sometimes succeeded when farmers have asserted claims for crop damage from drift of herbicides and pesticides against manufacturers and sellers. Courts have reasoned that improper application of those products by other persons (the farmer or someone hired to apply the product) caused the harm - not the products themselves, which are safe if properly used."

Conversely, secondary defendants, but not the end users of the product (the GMO farmers), may have tort liability if the underlying theory is negligence. ${ }^{118}$ The secondary defendants may have a greater appreciation of the risks that their GMO product poses to nearby nonGMO farmers than the GMO farmers who buy and plant the patented seeds. Their superior knowledge would mean that, under standard tort law principles, they may have a duty to warn the GMO farmers of the risks and how to control, manage, and minimize those risks by, for example, leaving appropriate buffer zones. A failure to warn, or inadequate warning, might be grounds for negligence-based liability on the secondary defendants, even when the injured party is not the seed buyer, but a bystander.

\section{A. Private Nuisance}

Today nuisance is the most common legal remedy for activities that adversely affect a property owner's land. ${ }^{119}$ Of the various tort theories, nuisance provides pollen drift plaintiffs with the best opportunity for recovery. All injured bystanding farmers should not necessarily recover. Nuisance liability for pollen pollution should attach under a balancing approach that examines a multitude of facts that are particular to both of the farming operations. ${ }^{120}$ This regime allows courts to fashion liability rules that are responsive to efficiency considerations, including switching costs and the role that transaction costs may place in blocking wealthenhancing exchanges by the parties. ${ }^{121}$

Nuisance law is highly flexible and adaptable. With that virtue comes indeterminacy. Nuisance law, long ago called by Prosser an "impenetrable jungle," ${ }^{\prime 2}$ is riddled with uncertainty. Not only do courts differ as to the overall scope of the field, they display markedly different

117. See, e.g., Braly v. Midvalley Chem. Co., 13 Cal. Rptr. 366, 368 (Dist. Ct. App. 1961) (finding that fertilizer was, like other similar substances, only dangerous when applied excessively).

148. See sapra note $1 t^{2}$.

i19. See Jacqueunne P. Hand a James Cunrles Smms, Neggrooking Proferty Owners 14 (1988). 120. See infra Part III.A.3.

121. See infra note t67 and accompanying text.

122. Pkosser, supra note $112, \$ 71$, at 549 . 
ideas about the nature of the landowner's right that ought to be protected by nuisance. Due to the amorphous nature of nuisance, there is more state-by-state variation in legal approach than for most other basic fields of tort law. Therefore, we base the following discussion on some general propositions for which there is broad, but far from universal, consensus.

Nuisance is often said to be a relative concept - it is a relative tort, it gives rise to a relative property right. It balances the gravity of the injury to the plaintiff against the utility of the defendant's conduct to arrive at a judgment as to whether a nuisance has taken place. ${ }^{123}$ This oversimplifies, but a core of relativity does exist. When a set of facts falls within the core, balancing (by the court, the finder of fact, or both) takes place. The defendant's conduct is found to be a nuisance if it is said to be unreasonable, considering all the facts and circumstances, including the unreasonable, consid
plaintiff's position.

Nuisance, however, has two other zones, lying on opposite sides of the balancing core. These zones may ultimately either insulate the defendant from liability, or may impose liability on the defendant regardless of the reasonableness of the activity. Both of these zones give us bright-line rules. The first zone is what we may call nuisance inmunity. us bright-line rules. The first zone is what we may call nuisance immunity. Certain landowner activities are regarded as sufficiently beneficial or benign that courts virtually never castigate them as nuisances. Such activities are privileged and are not subject to nuisance balancing. An important caveat is that for some types of activities the landowner must conduct the activity in a non-negligent fashion. In a case falling within the nuisance immunity zone, the defendant is free from nuisance liability.

Second, there is the nuisance per se doctrine. Certain conduct, perceived as generally undesirable or high risk, is always wrongful. If an owner or possessor of land has engaged in that conduct, a neighbor can get relief (enjoin the nuisance or collect damages), without the need to get relief (enjoin the nuisance or collect damages), without the need to prove that the conduct is unreasonable. Nuisance per se is properly seen as a species of strict liability, even though many courts choose not to discuss it in those terms. We also discuss nuisance per se later in connection with strict liability. ${ }^{12}$

123. RESTATEMENT (SECOND) OF TORTS 5826 (1979)

124 See infra notes $221-225$ and accompanying text.

\begin{tabular}{|c|c|c|}
\hline $\begin{array}{c}\text { Nuisance } \\
\text { Immunity }\end{array}$ & Nuisance Balancing & $\begin{array}{c}\text { Nuisance Per Se: Strict } \\
\text { Liability }\end{array}$ \\
\hline
\end{tabular}

\section{Immunity Cases}

Different types of activities qualify for nuisance immunity. One example is the refusal of American courts to grant relief for improvements that block views ${ }^{125}$ or deprive a neighbor of sunlight or air. ${ }^{126}$ Another is the doctrine of aesthetic nuisance, which holds that improvements or landscape modifications cannot constitute a nuisance if the only harm to neighbors is aesthetic blight. ${ }^{127}$ Thus, the ugliest grain silo in the world, even when located next to a neighbor's boundary and shadowing her sundeck, is not actionable. ${ }^{128}$

For our purposes, a small body of old cases involving noxious plants, sometimes judicially identified as "weeds," provides the closest analogy. These cases immunized owners of weed-infested properties from nuisance liability when the weeds germinated and "polluted" nearby crops. In a representative case, an Iowa court held that a farmer whose lands were "greatly damaged" by a cocklebur infestation had no cause of action. ${ }^{129}$ The line of authority in the case reports died out close to a

125. See, eg., 44 Plaza, Inc. v. Gray-Pac Land Co, 845 S.W.2d 576, 578 (Mo. Ct. App. 1992) ('[L]andowner's otherwise lawful acts in blocking the view of another's property do not give rise to cause of action for nuisance."); Hay v. Weber, 48 N.W. 859, 860 (Wis. 189r) (holding obstruction of view is "too remote and speculative to constitute the basis of a private action" for nuisance).

126. See, eg., Sher v. Leiderman, 226 Cal. Rptr. 698, 7or (Ct. App. 1986) ("(B)lockage of tight to a neighbor's property, except in cases where malice is the overriding motive, does not constitutc actionable nuisance, regardless of the impact on the injured party's property or person.").

127. See, eg., Whitmore v. Brown, 65 A. 516, 521 (Me. 1906) (holding unsightly wharf not infringement on neighbor's legal rights); Perry Mount Park Cemetary Ass'n v. Netzal, 264 N.W. 303. 303 (Mich. 1936) ("[M]ere esthetics is beyond the power of the court to regulate."); Ness v. Albert, 665 S.W.2d I, I-2 (Mo. C. App. 1983) ("(U)nsightliness, without more, does not create an actionable nuisance."); Houston Gas \& Fuel Co. v. Harlow, 297 S.W. 570, 572 (Tex. Civ. App. 1927) (holdin unsightly structure does not constitute nuisance); Parkersburg Builders Material $\mathrm{Co}$, v, Barrack, I9 S.E. 365,369 (W. Va. I937) ("[C]ourts of equity have hesitated to exercise authority in the abatemen of nuisances where the subject matter is objected to by the complainants merely because it is offensive to the sight.").

128. See, eg., James Charles Smith, The Law of Yards, 33 EcoLody L.Q. 203, 215 D.47 (2006) (cellular tower towering over neighboring property is not actionable).

129. In Hamdon v, Stulfz, 100 N.W. 851, 852 (lowa 1904), defendant "allowed cocklebur and other noxious weeds to grow in large quantities" near the boundary line. Due to wind and a natura watercourse, the weed spread to plaintiff's lands, "whereby the same has been greatly damaged " Id Rejecting plaintiff's claim for damages and an injunction, the court observed, without further analysis "The proposition is unique, to say the least. It is not sugrested that the growing by one upon bis ow land of cocklebur and weeds is without legal right ...." Id. 
century ago, probably for two reasons. First, the common-law nuisance no-duty-to-control-weeds rule became entrenched. New challenges by injured landowners may have seemed pointless. Second, and more importantly, the no-duty rule led to legislative intervention. Local governments first enacted weed control ordinances during the late nineteenth century to protect farmers' crops from the spread of weeds. ${ }^{130}$ Subsequently, weed ordinances spread to urban and suburban settings. ${ }^{13 !}$

At first blush, the noxious plant cases might support immunizing the GMO crop defendants from liability. Both fact patterns involve an invasion by reproductive parts of plants: seeds and pollen. There are, however, two critical distinctions. First, some courts have considered relevant the question whether the plants on the defendant's land grew accidentally, or whether the defendant purposely planted them. English cases involving poisonous trees and thistles illustrate the distinction. Landowners who plant yew trees are liable in nuisance for harm to livestock if branches and leaves project over the boundary. ${ }^{132}$ But andowners who allow thistles to grow on their land are not liable when they spread, injuring a neighbor's land. ${ }^{133}$ The general principle is the amiliar one that discriminates between a person's action and inaction. This rests on the commonsense notion that ordering a person to take preventative measures is more onerous than ordering a person to stop doing something that injures another person. With respect to the bystanding farmer, the prototypical defendant has intentionally planted the GMO crops. The GMO crops are not weeds that accidentally infiltrated the defendant's land.

A second distinction between the noxious plant cases and GMO pollen drift concerns the legal status of the invading substances. In the

130. See, e.g. Ind. Code Ann. 8 8-3-7-I (LexisNexis 1998); Tex. Rev. Civ. Stat. Anv, art. 640 (Vernon 1926); see also Chicago. Terre Haute \& Se, Ry, y. Anderson, 242 US. As , 288 (1916) (upholding constitutionality of Indiana law); Mo, Kan. \& Tex. Ry. Co. y. May, 194 U.S. 267, 270 (1916) (upholding Texas law). These statutes usually delegated to local government the power to ordinances specifying the types of prohibited vegetation, the landowner'sent the power to enact procedures for official notice to offending landowners, and enforcement mechanisms.

131. See Smith, supra note ias, 1215 .

132. Crowhurst v, Burial Bd, $(1878)$ 4 Exch. Div, 5,6 (plaintiff's horse died from eating yew tree leaves). Distinguishing Crowhurst, the court in Ponting v. Noakes, (1894) 2 Q.B.D. 281, 291, denied leaves). Distinguishing Crowhurst, the court in Ponting V. Noake, (1894) 2 Q.B.D. 281 , 29I, denied recovery when plaintiff's colt extended its head across a boundary fence to eat leaves that were wholly on defendant's land. The English courts viewed the cases as raising questions about the scope of Rylands v. Fletcher, (1868) 3 L.R.E. \& I. App. 330 (H.L.). In the former, but not the latter case, the defendant allowed a dangerous thing to escape from his lani.

133. Giles ₹. Walker, (I890) 24 Q.B.D. 656 (after defendant burned gorse to improve land for grazing, numerous thistles emerged; jury found defendant to be negligent, but appellate court
reversed). noxious plant cases, as in standard pollution cases, the defendant polluter does not assert an ownership interest in the emitted material. ${ }^{14}$ Certainly, these substances were owned by the polluter prior to their escape from the polluter's land. Afterwards, legal ownership is abandoned. In the usual cases pollutants like weed seeds and pollen, leaves, dirt, dust, or smoke almost invariably have no value. But if a victim of pollution can "harvest the pollution" and find an economically valuable use for it, she is free to keep the substance. Surely the polluter, as original owner, cannot get it back and has no claim for compensation. Suppose a landowner's operations propitiously emit gold dust through the air or water, which a neighbor captures. Now it's her property.

Conversely, retained ownership of a thing that enters a neighbor's tract generally makes the owner liable for damages. This is why owners of domesticated animals are usually strictly liable when they stray, and why in contrast, landowners are not liable if unconstrained wild animals exit their land and damage a neighbor's land. ${ }^{135}$ If owners of wandering livestock forfeited ownership of their animals to the neighbors, perhaps the neighbors would not have damage actions. In many cases, the victims of animal trespass would consider the exchange a fair quid pro quo; the animals' value would equal or exceed the injury caused by the animals. ${ }^{.36}$

In the GMO pollination situation, the defendant who holds a valid patent is like the owner of straying domestic animals. The GMO farmer is sending a substance on her neighbor's land, but the patentee still claims to retain ownership of it. Due to patent law, the neighboring farmer cannot feel free to use the pollen however she sees fit. Just as a neighbor cannot capture and sell livestock that have entered her land, she cannot intentionally capture and utilize the patented pollen. ${ }^{13}$ ? Because of the three-party nature of the pollen drift scenario, the

134 Ser Gulf, C. \& S.F. Ry. Co. v. Oakes, 58 S.W. 999 , 1001 (Tex. 1900) (pointing out that after Bermuda grass invades neighbor's land, neighbor owns it completely, and can do with it what he pleases).

135. See Prosser \& Keeton, supra note 111, $\$ 76$.

136. A classic case dealing with migrating oil and gas demonstrates the impact on liability of the decision as to whether the original owner has retained ownership of the escaped property. Hammonds v. Cent. Ky. Natural Gas Co., 75 S.W.2d 204, 206 (Ky. C. App. 1934) (holding that company that reinjects natural gas into depleted underground reservoir is not liable in trespass to neighbors who own part of reservoir because company has lost ownership of gas, which is like wild animal released into natural habitat).

137. It makes no difference that the GMO crop farmer lacks the contractual right to let her neighbor use the patented goods that have escaped. First, in buying seeds, she bargained for limited rights to use the patent. Second, the patent owner will often be a co-defendant, and that owner could choose to make the patented product freely available to non-GMO farmers who are subjected to pollen invasion. 
retained ownership distinction made in the old wandering livestock cases is not precisely on point. Nonetheless, we feel relatively certain that common-law principles do not justify granting nuisance immunity to GMO defendants, especially in light of a recent pollen drift case that applies a balancing approach. ${ }^{138}$ This means that in nuisance litigation, defendants are not entitled to summary judgment, provided plaintiffs have alleged, and can introduce evidence of, substantial harm and causation (i.e., that defendants are the source of the offending GMO pollen).

\section{Right-to-Farm Acts}

Although GMO defendants have no plausible claim to common-law nuisance immunity, a legislature may choose to confer immunity, provided it acts in a constitutionally valid manner. ${ }^{139}$ Since the 1970 , all states have enacted right-to-farm statutes ${ }^{40}$ that shield agricultura operations from nuisance liability under certain circumstances. Despite the substantial diversity among the states in statutory content, as well as divergences in judicial interpretation, few GMO defendants will be able successfully to invoke a right-to-farm statute as an affirmative defense.

Right-to-farm laws protect farms from nuisance liability by insulating existing farm operations when a nuisance arises from the changing nature of the surrounding area. ${ }^{14}$ The prototypical conflict addressed by right-to-farm acts involves a homeowner, recently resettled from the city or suburbs, complaining about agricultural odors or other agricultural externalities. The right-to-farm law enacts a "coming to the nuisance" defense, preserving existing agricultural uses, no matter how fervently the city slickers complain that they cannot enjoy their newly acquired properties. ${ }^{14}$ Because right-to-farm laws are targeted at these specific factual situations, some courts have held that right-to-farm acts

138. In In re StarLink Corn Products Liability Litigation, 212 F. Supp. 2 d 828 (N.D. IIL. 2002), the liability of neighboring farmers on nuisance grounds seems to be taken for granted in the larger discussion of whether GMO seed distributors and manufacturers are liable. Id at \&u- 45 .

139. See Bormann v. Bd. of Supervisors, 584 N.W. $2 d$ 309, 321 (Iowa 1998) (concluding that locel government's approval of agricultural area designation for 960 acres, which entitles owners to statutory immunity, is unconstitutional taking of neighbors' property). In addition, an extensive legislative grant of immunity to GMO defendants might violate federal due process, See John CP. Goldberg, The Constitutional Stanus of Tor Law: Due Process and the Righr to a Law for the Redress of Wrongs, IIS YALE L.J. 524,540 (2005).

140. See Alexander A. Reinert, Note, The Right to Farm: Hog-Tied and Nuisance-Bound, 73 N.Y.U. L. REv. 1694,1706 n.76 (1998) (citing fifty state statutes).

41. Grossman, supra note 9, at 233-34.

142. See id. (arguing that those who come to the nuisance have only themselves to blame (citing Reinert, supra note 140, at 1703)). do not apply to actions brought by agricultural plaintiffs. ${ }^{16}$ It is also generally likely that the complaining farmer will have historically used his neighboring land for farming purposes, thus not changing the nature of the surrounding area. ${ }^{144}$ In other words, when farmers sue farmers, the common law often applies; there is no statutory immunity. A Washington case is illustrative. In Buchanan v. Simplot Feeders Ltd. Partnership, ${ }^{14}$ farm owners brought a nuisance action complaining about manure dust, flies, and odors from a neighboring cattle feedlot and meat processing plant, both of which had recently expanded in scale of operation." Finding the Washington right-to-farm statute to be ambiguous, the court interpreted it to apply only to conflicts stemming from urban encroachment. ${ }^{197}$ Thus, it did not immunize agricultural enterprises from nuisance actions brought by an agricultural or other rural plaintiff ${ }^{148}$ In contrast, a California court concluded that its state right-to-farm act conferred immunity upon a rice farmer when a neighboring plaintiff farmer complained that the rice farming caused excessive water seepage, damaging plaintiff's row crops. ${ }^{169}$

A number of other requirements for statutory immunity may disqualify some GMO defendants. First, the GMO farming activity may have to meet a minimum time period for operation before it achieves immunity. In California, the period is three years. ${ }^{190}$ Second, if the bystanding farmer's use commenced prior to the GMO farming, immunity is unlikely. ${ }^{15 t}$ This factor, which reflects the "coming to the nuisance" origin of the right-to-farm acts, often will have a decisive impact. ${ }^{157}$ Frequently the bystanding farmer will have begun organic or

143. See, e.g., Buchanan v. Simplot Feeders Ltd., 952 P.2d 610, 614 (Wash. 1998) (interpreting Washington's statute as requiring a non-agricultural plaintiff). But see Souza v. Lauppe, 69 Cal. Rptr. 2d 494, 496 (Ct. App. 1997) (construing California's statute to apply to cases with either nonagricultural or agricultural plaintiffs).

144. Grossman, supra note 9, at 234 (arguing that a suit against a GMO farmer will usually be brought by a neighboring farmer who grows traditional crops).

145. 952 P.2d 610

145. 952 P.2d 610.

146. Id. at 614

148. Id. at 616

149. Souza, 69 Cal. Rptr. 2d at 494 (affirming summary judgment for the defendant because the state right-to-farm statute applies broadly to bar a nuisance action resulting from changed conditions). I50. See CAL. Crv. Code 8 3482.5(a) (West 1997); Souza, 69 Cal. Rptr. 2d at 496-98, 500.

ISt. For example, the Vermont (net

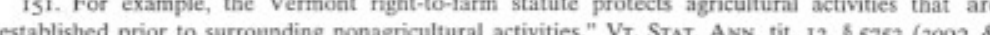

152. In Souza, the plaintiff's recent switch from rice farming to row crops constituted the required "changed condition in or about the locality." 69 Cal. Rptr. 2d at 500-0I (eiting $\$ 3482.5(\mathrm{a})(\mathrm{r}))$. In Buchanan, the court counted in the plaintiff' favor their ownership and operation 
non-GMO farming before, sometimes long before, the defendant introduced GMO crops to the neighborhood. Third, the defendant's agricultural use may have to meet industry standards. ${ }^{159}$ Compliance with federal regulations may not suffice. The Michigan act points to state regulatory norms. ${ }^{154}$ The California statute is more diffuse, pointing to undefined local norms. ${ }^{15 s}$ This probably means that no immunity is available unless GMO farming is commonly practiced in the locality. If it is rare (e.g., the defendant is the only local GMO farmer), by definition defendant has departed from the industry standard.

\section{Nuisance Balancing}

Nuisance's large middle zone, classically called nuisance per accidens (in contrast to the bright-line nuisance per se rule), balances a number of factors to determine which party has a property entitlement. Often but not always the decision-maker is the jury or other trier-of-fact; whether a nuisance exists is said to be a mixed question of fact and law. ${ }^{156}$ The nature of the balancing test is flexible enough to allow a court to consider

of their farm since 196t, noting that "it is the Buchanan family farm that is being forced oun by the expanding enute feedlot and industriallike beef processing facility. "952 P ad at 6ro. The cont expanding cattle feedlot and industrial-like beef processing facility." 952 P.2d at 613 . The cour ctions brousht by an agricultural or other rural plaintiff, especially if the plaintiff oceupied the land

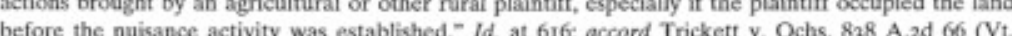
(lolore the facilities for apple waxing and storase, are not entitled to statutory immunity when the buyers of a filities for apple waxing and storage, are not)

153. Some right-to-farm acts expressly provide that the defendant's activity must be conducted without negligence. See, e.g. IND. CODE ANN. \& 32-30-6-9(a) (West 2002 \& Supp. 2005) (-This section does not apply if a nuisance results from the negligent operation of an agricultural or industrial operation or its appurtenances."). Ofen this will serve as a proxy for compliance with industry custom and standards.

154. Mich. Comp. Laws ANn. \$ 286.473(3)(1) (West 2003) provides:

A farm or farm operation shall not be found to be a public or private nuisance if the farm or farm operation alleged to be a nuisance conforms to generally acoepted agricultural and management practices according to policy determined by the Michigan commission of agriculture. Generally accepted agricultural and management practices shall be reviewe

155. CAL. Civ. CODE $\$ 3482.5(\mathrm{a})(\mathrm{r})$ (West 1997) (emphasis added) provides:

No agricultural activity, operation, or facility, or appurtenances thereof, conducted or maintained for commercial purposes, and in a manner consistent with proper and accepted same locality, shall be or become a nuisance, private or public, due to any changed condition in or about the locality, after it has been in operation for more than three years if it was not a nuisance at the time it began.

156. See, e.g., Escobar v. Cont'7 Baking Co., 596 N.E.2d 394, 396 (Mass. App. C. 1992) (reversing trial court conclusion that nighttime noise from deliveries to bakery was unreasonable and thus nuisance because nuisance is a "mixed question of law and fact" (quoting Melrose Hous. Auth. v. N.H. Ins. Co., 520 N.E.2d 493. 497 n-4 (Mass. 1998))). to liability identified in Part 1 of this Article, e.g., farming methods, typical crop yields, costs of production, market values, the the availability of alternative seeds and protective This is not to say that magnitude of each farmer's switching costs. judges will inevitably render wealth-enthancing economic tools necessary balancing approach

for efficient results.

In the nineteenth century, American courts began In the ninetertantial classic view of nuisance, which held a defendant lis a growing harms caused by its invasions. Industrialization gave rants and their numbers of conflicts between industrial defendants anst emerging neighbors. ${ }^{159}$ Judges became reluctant to assess damages against enuisance industries, ${ }^{160}$ and they avoided damage liability by refocusing tand to doctrine. ${ }^{16}$ If the defendant was acting reasonably in devolinge without doctine. an industrial activity, the ders nective led to having to pay its neighbors. expanded view of reasonableness. Anefits flowing from the defendant's of the harm conduct. ${ }^{36}$

(he modern, post-ir The Restatement of Torts follows the marties' conduct. With respect and applies a reasonableness filter to both partion of:

to the gravity of the harm, it calls for evaluation of: haracter of the harm

(a) The extent of the harm involved; (b) the chaches the type of use or involved; (c) the social value that the law at of the particular use or enjoyment invaded; (d) the suitability locality; and (e) the burden enjoyment invaded to the character of the local

on the person harmed of avoiding the handents conduct, the

With respect to the utility of the defendant's conduct, the Restatement points to: "(a) the social value that the law attaches to the primary purpose of the conduct; (b) the suitabicability of preventing or primary pucality; and (c) the impracticability of preventing or

7. See supra Part I

Tine Tunseopuanox of Ameracan Law, 1780-1860, at $70-104$ $(158.5$

(1)

160. Td.

161. Th.

163. Id.

64. Id.

165. Resta 
avoiding the invasion." 160

The Restatement approach may have the virtue of being flexible and adaptable, but it does not compel any particular result in any imaginable nuisance dispute. Multi-factor analysis incorporating these eight variables produces a level of indeterminacy that is difficult to surpass. ${ }^{167}$ However, the flexibility inherent in the approach allows for the incorporation of the economically relevant factors we have identified. As Coase noted after his discussion of common law nuisance cases taking a balancing approach, "[t]he economic problem in all cases of harmful effects is how to maximize the value of production .... [and] the courts have often recognized the economic implications of their decision and are aware (as many economists are not) of the reciprocal nature of the problem."

In justifying their outcomes, modern courts have often applied the Restatement nuisance criteria. To the extent that nuisance law has a modicum of certainty and predictability, it comes from outside the Restatement from reported cases. This means that trial courts and appellate courts are constrained in their nuisance decision-making only by in-state judicial precedents. This is especially significant for the issue at hand-under modern nuisance balancing, will courts (should courts?) find GMO defendants liable when their pollen contaminates the crops of bystanding farmers? Because there are no judicial precedents, the question is wide open. Any competent judge can write an opinion, using the Restatement factors (or equally malleable factors set forth in state decisional law) to announce or to reject liability, or to validate a jury verdict in either direction. This, of course, creates room for the consideration of farming methods, typical crop yields, costs of production, market values, the availability of alternative seeds and

\section{6. $I d$.}

[67. Many scholars see legal indeterminacy as a vice. See, e.g., Susan Rose-Ackerman, Against Ad Hocery. 4 Comment on Michelman, 88 Colum. L. REv, 1697 (ro88) (arguing that formal principles in the context of takings are more desirable than a less formal balancing approach). Others see it as a virtue, at least in sog contexts. Sec Mare R. Poirier, The Virtue of Vaguenss in Takings Doctrine, Ca

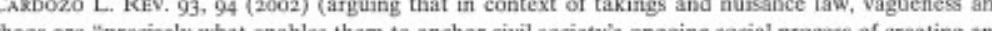
revising other, more crystallized expressions of property law").

168. ConsE, supra note 2, at 114,120

Furthermore, from time to time, [the courts] take these economic implications into account, along with other factors, in arriving at their decisions. The American writers [citing Prosser] on this subject refer to the question in a more explicit fashion than do the British.... An 14. at 120-2I. protective measures, and the magnitude of each farmer's switching costs, which should be relevant in determining liability.

Doctrinal indeterminacy has one highly important consequence for GMO nuisance litigation. Although some of the Restatement considerations do not raise issues that are purely factual (some present mixed questions of fact and law), in almost every case fact-finding will be necessary. Cases will survive motions for summary judgment and necessary. Cases wirt (or to the court as fact-finder if there is no jury). A proceed to the jury (or to the court as fact-finder if there is no jury). A summary dismissal will take place only when the bystanding farmer sued the wrong defendant or has failed to allege substantial economic harm caused by cross-pollination.

The one reported American case, In re StarLink Corn Product Liability Litigation, demonstrates how easily bystanding farmers can survive the summary judgment stage. ${ }^{169}$ Corn farmers brought actions against the developer and distributor of StarLink corn, asserting multiple claims including private nuisance, public nuisance, negligence, strict liability, and conversion. ${ }^{170}$ The plaintiffs did not, however, sue the nearby StarLink corn farmers. ${ }^{\text {IT }}$

StarLink corn is genetically engineered to produce a protein, CrygC, that is toxic to certain insects. ${ }^{172}$ Because $\mathrm{Cry9}$ C has an attribute simila to human allergens, the Environmental Protection Agency (EPA) to human starLink for animal feed and other uses, but not for human consumption. ${ }^{73}$ Due to cross pollination, StarLink allegedly contaminated "the entire United States' corn supply," causing a drop in value of U.S. corn. ${ }^{174}$

The StarLink district court dismissed certain claims, but not the misance claims. ${ }^{175}$ The court cursorily observed, "We agree that drifting pollen can constitute an invasion, and that contaminating neighbor's' crops interferes with their enjoyment of the land. The issue is whether crofs inter product beyond the point of sale." ${ }^{176}$ The court assumed, without further discussion, that the StarLink plaintiffs could assert a valid nuisance claim

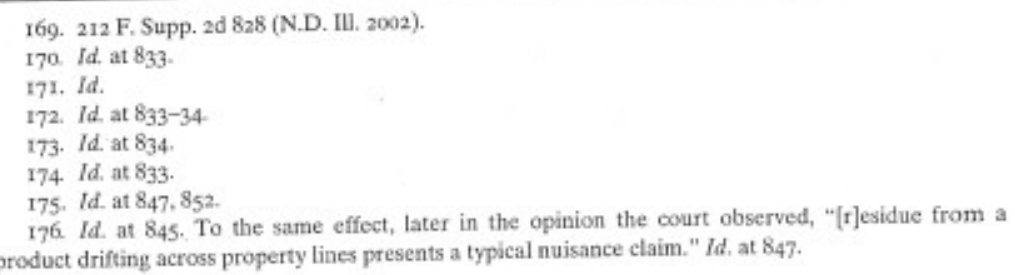


against their neighbors. ${ }^{\text {in }}$ All of the court's attention was directed to defendants' claim "that they cannot be liable for any nuisance caused by StarLink because they were no longer in control of the seeds once they were sold to farmers." 778 The court denied the motion to dismiss, concluding that defendants' design of the StarLink technology, distribution of the seeds, and an alleged failure to comply with EPA requirements might constitute substantial contribution to the nuisance. ${ }^{.79}$

\section{B. Strict Liability}

Another potential cause of action available to non-GMO farmers is strict liability resulting from activities of the defendant that are deemed "abnormally dangerous." "Ino In theory, strict liability requires no fuzzy balancing of interests, no negligence on the part of a defendant, and no bad intent on the part of the defendant. Where applicable, it might provide another useful legal tool for bystanding farmers.

There is no ready answer to the question whether private nuisance, in whole or in part, is a strict liability tort. It turns on two variables: how broadly one defines "nuisance" and how one perceives "strict liability." The Restatement authors define nuisance expansively as any "nontrespassory invasion of another's interest in the private use and enjoyment of land." ${ }^{183}$ Other authorities define nuisance more narrowly, as an intentional tort. ${ }^{182}$ One view of strict liability limits that field to harms caused accidentally and without negligence. ${ }^{18_{3}}$ For our purposes, these questions of theory and doctrinal definition make no practical difference. Since the American acceptance of Rylands v. Fletcher, ${ }^{184}$ it has

\section{Id. at 847 .}

178. Id. at 845 .

179. Id. at 844-47. The court discussed cases involving asbestos and guns, where some courts imposed but others rejected nuisance liability for manufacturers beyond the point of sale. Id. at 845 . The court concluded that the StarLink nuisance claim was stronger because the asbestos and gun cases did not involve injuries to neighbors of purchasers of the product. Id. at 846-47.

180. RESTATEMENT (SECOND) OF TORTS $\$ 520$ (1977); accord Endres, supra note 21, at 488 (observing strict liability applies when a defendant engages in an abnormally dangerous activity); Repp, supra note 9, at 616-20 (discussing the application of strict liability for abnormally dangerous GMO farming activities).

181. RISTATEMENT (SECOND) OF TORTS 5 821D (1979).

182. See, e.g. Prosser \& KEETON, supra note III, \& 91.

183. Id. 575 , at $534-36$.

184. (1868) 3 L.R.E. \& I. App. 330 (H.L) (identifying in English courts the doctrine of strict liability for inherently dangerous activities). Shortly after the Rylands decision, some American courts rejected the doctrine. See, eg., Brown v. Collins, 53 N.H. 442, 450 (1873) (calling absolute liability not suitable for a society with "modern, progressive, industrial pursuits"). For a modern example of the American application of the Rylands doctrine, see Siegler v. Kuhlman, 502 P.2d $118 \mathrm{I}$ (Wash. 1972). For a discussion of the several landmark strict liability torts cases, see R. Perry Sentell, Jr., Torts in been abundantly clear that one landowner can be strictly liable for harm caused to a neighbor, whether the rule is seen as a species of nuisance or just plain strict liability.

The strict liability theory is attractive to bystanding farmers because, unlike a negligence theory, strict liability does not require proof of fault so long as the activity is considered abnormally dangerous. ${ }^{155}$ The rationale behind the doctrine of strict liability is that there are certain activities that present such serious danger that persons engaging in those activities should automatically bear the costs of any injury resulting therefrom. ${ }^{1 \otimes 6}$

To determine whether an activity is abnormally dangerous, the Restatement calls for courts to consider six factors:

(a) existence of a high degree of risk of some harm to the person, land or chattels of others; (b) likelihood that the harm that results from it will be great; (c) inability to eliminate the risk by the exercise of reasonable care; (d) extent to which the activity is not a matter of common usage; (e) inappropriateness of the activity to the place where it is carried on; and (f) extent to which its value to the community is outweighed by its dangerous attributes. ${ }^{\text {tin }}$ ?

Courts should consider all six factors, but some factors may weigh more heavily than others and it is not required that all six be present. Although the theory of strict liability has been used less frequently than other theories of recovery because the six elements are somewhat difficult to prove, it remains a viable and attractive option to the plaintiff, simply because a finding of strict liability ensures recovery without any proof of fault.

Conceivably, those who participate in the production of GMO crops might sometimes be held strictly liable for losses caused to neighbors under the Rylands doctrine or its Restatement six-factor derivative. ${ }^{190}$ To

Verse: The Foundational Cases, 39 GA. L. Rev. 1197, 1312-25 (2005).

185. See Flood, supra note 7, at 487-88 ("Examples of abnormally dangerous activities include toring and using explosives, spraying pesticides, spilling toxic substances, allowing the escape of sewage, and allowing the escape of noxious or poisonous gases, fumes or vapors."' (quoting Repp supra note 9, at 616)).

186. Id. at 488 .

187. RESTATEMENT (SECOND) OF TORTS \& 520 (I977)

188. See Endres, supra note 2I, at 488 .

189. See Repp, supra note 9, at 617 .

190: The Restatement standard is as follow:

(I) One who carries on an abnormally dangerous activity is subject to liability for harm to the person, land or chattels of another resulting from the activity, although he has exercised the utmost care to prevent the harm.

(2) This strict liability is limited to the kind of harm, the possibility of which makes the 
illustrate application of the six factors in pollen drift cases, the pesticide drift cases provide an analogy. Two of the leading cases, one from Washington and the other from Wisconsin, reached opposite conclusions. In Langan v. Valicopters, Inc, ${ }^{192}$ pesticides applied by helicopter drifted across a farm boundary, falling on the plaintiffs' organic crops. Laboratory testing proved that the crops were contaminated with Thiodan, a chemical used to prevent Colorado beetle infestations, and resulted in the decertification of the plaintiffs' entire crop of tomatoes and beans as eligible for sale as organic produce. ${ }^{193}$ The plaintiffs recovered compensatory damages in the amount of $\$ 5500$ for the market value of the crops based on a jury instruction calling for strict liability for damage proximately caused by the pesticides. ${ }^{394}$ The Supreme Court of Washington affirmed, applying the Restatement strict liability factors ${ }^{165}$ as discussed in the following sections.

\section{Risk of Harm}

The Langan court found it "undisputed" that crop dusting did present a high degree of risk of harm. ${ }^{19}$ It concluded that the practice presented three "uncertain and uncontrollable factors: (I) the size of the dust or spray particles; (2) the air disturbances created by the [applicating aircraft]; and (3) natural atmospheric forces," noted that it is virtually impossible to control or limit the risk of drift posed by crop dusting. ${ }^{198}$ It seems likely that a court would recognize similar "uncertain and uncontrollable factors" in the pollen drift situation: (I) the size of the pollen particles is very small, like pesticides; and (2) pollen drifts in the air by way of "normal atmospheric forces" such as wind, as do pesticides. ${ }^{199}$ Like crop dusting, the planting of GMO

activity abnormally dangerous

RESTATEMENT (SECOND) OF TORTS $\$ 5 \mathrm{sg}$ ( 1977 )

191. See Robert F. Blomquist, Applying Pesticides: Toward Reconceptualizing Liability to Neighbors for Crop, Livestock and Personal Damages from Agricultural Chemical Drift, 48 OKL. L. REv. 393, 397-412 (1995) (discussing pesticide drift cases).

192. 567 P.2d 218 (Wash. 1977).

193. Id. at $219-20$.

194. Id. at 220. The trial court gave the following instruetion: "[i]f you find that defendants' chemicals fell upon plaintiffs' crops, you are instructed that as a matter of Law the defendants are liable for such damage to plaintiffs' crops, if any, as you find was proximately caused by defendants' spray application." Id.

195. REsTATEMENT (SECOND) OF TokTs \$ 520 (1977).

196. Langan, 567 P.2d at 222.

197. $I d$.

199. Id. (referring to article which notes that use of helicopters yeduces but does not eliminate risk of drift).

199. Sec Flood, supra note 7, at 489 . seeds bears a high risk of harm that cannot be eliminated because the contamination is aided by natural uncontrollable forces like wind and insect pollination. ${ }^{2 x 0}$

2. Likelihood of Great Harm

In determining whether the gravity of the harm will be great, the Langan court noted that it is important to consider the use of the adjoining land ${ }^{20 t}$ In other words, in order for there to be great harm, the adjoining landowner must use her land in such a way that the chemicals will cause harm. ${ }^{20}$ For example, where an adjoining landowner keeps hogs on the property, the likelihood of harm resulting from the neighbor's dusting of arsenical is great. ${ }^{2 n 3}$. The Langan court found that in the plaintiffs' situation, there was the likelihood for great harm because the organic farmer risks losing his certification if nonorganic materials the organic farmer risks ${ }^{204}$ Without the certification, the farmer would are applied to the crops. ${ }^{204}$ Without the certification, the farmer would
suffer economic damages when he could not sell the crops in the organic market.

The court's analysis of the likelihood of great harm for the organic farmer is analogous to that which would apply in a pollen drift scenario. Under the various rules governing the certification of organic crops, genetic contamination equates to the application of nonorganic materials to the crops; "[c]urrently, "no private or governmental certification to the crops; "[c]urrently, no private or GMO seeds." organic farmer whose crops are GMO-contaminated could easily prove the gravity of the harm by way of his economic losses.

\section{Exercise of Reasonable Care}

Concerning the defendants' inability to eliminate the risk by the exercise of reasonable care, the Langan court simply noted that the same factors that produced a high degree of risk of harm were not possibly eliminated by the use of reasonable care. ${ }^{306}$ In the context of corn pollen drift, GMO farmers probably similarly cannot completely eliminate the high risk of harm. With a crop like soybeans, however, GMO farmer may be able to employ small, effective buffer zones. Thus, it is likely that

200. $I d$.

21. Langan, 567 P.2d at 22

202. Id.

203. Id. (citing McPberson v, Billington, 399 S.W.2d 186 (Tex. Civ. App. I965))

204. Id. at $222-23$. Acceptance of Biotechnology and Geretically Modified Organisms, 6 Drake J. AGuc. L. 81, 104 (2001)).

206. Langan, 567 P 24 at 222-23. 
the use of reasonable care on the part of the GMO farmer will depend on the type of crop planted.

\section{Common Usage}

In determining whether the activity was a matter of common usage, the Langan court employed the Restatement's approach that "[a]n activity is a matter of common usage if it is customarily carried on by the great mass of mankind, or by many people in the community." ${ }^{107}$ The court rejected defendants" argument that crop dusting was "common usage," militating against strict liability, observing: "Although we recognize the prevalence of crop dusting and acknowledge that it is ordinarily done in large portions of the Yakima Valley, it is carried on by only a comparatively small number of persons (approximately 287 aircraft were used in 1975$) \ldots . .,{ }^{200}$ Given the popularity of some GMO crop strains, ${ }^{209}$ an argument in favor of common usage could be supported by a defendant, especially in the case of soybeans and canola, where $85 \%$ and $84 \%$ of acreage, respectively, is planted in GMO strains. ${ }^{210}$

\section{Inappropriateness of Activity in the Place}

In considering the element of appropriateness, the Langan court found simply that the use of pesticides near organic farming operations is an activity that is inappropriate in that place." In the pollen drift situation, the activity of planting non-GMO crops in a place where the pollen may drift and contaminate non-GMO crops could similarly be considered an inappropriate activity.

6. Value to Community

Although the court in Langan found that spraying pesticides was valuable in that it increased yields and thus food production for the community, it eventually concluded that the appropriate analyses included a look at who was to bear the burden of even beneficial activities. ${ }^{2 *}$ The plaintiffs were innocent bystanders, and balancing the equities required the defendants, who enjoyed the benefits of the activity, also to bear the risks. ${ }^{2+3}$ Similarly, in the pollen drift situation, the benefits of GMO crops to the community may include increased food

207. Id. at 223 (quoting Restatement (SECond) of Tosts \& 520(i) (Tent. Draft No. Io, Io644)).

208. Id.

209. See Crre ron Food SAretr, supra note 8, at 8-9.

211. Flood, supra note 7, at $491-92$

2I2. Id. at 492 supply, but ultimately it is the innocent bystanding non-GMO farmer who is harmed, and it is the GMO farmer who benefits monetarily from the GMO crops. Under the Langan approach, the GMO farmer and the GMO biotech companies should bear the risks that accompany GMO farming since they are the parties who profit from the operations.

Although the Langan case provides a useful strict liability analogy to the pollen drift scenario, the fact remains that most cases brought to recover damages caused by pesticide drift proceed on a theory of negligence. While the case was once seen as a potential watershed movement toward the application of strict liability to an abnormally dangerous activity, it has in reality been embraced by few courts. ${ }^{214}$ In one of the few reported cases to discuss strict liability, the Wisconsin high court rejected strict liability and required a showing of negligence. In Bennett $v$. Larsen Co., a corn farmer sprayed his fields with pesticides to combat corn borers and earworms. ${ }^{215}$ Plaintiffs were beekeepers, with some of their hives near the corn fields. ${ }^{216}$ The pesticide labels indicated that the product may kill honeybees in substantial numbers. ${ }^{217}$ This happened. ${ }^{218}$ The court permitted plaintiffs' negligence claim to go forward, but rejected their claim of strict liability:

$[\mathrm{P}]$ esticide application to control severe pest infestations is a common activity which is necessary to ensure healthy crop growth. Testimony revealed that several canning companies in the Outagamic County area each year sprayed pesticides on their corn in order to avoid the potential complete destruction of their crops by corn borers and earworms. We conclude that the application of pesticides is a necessary and beneficial activity to ensure the production of adequate and healthy food and that its value to the people of this state outweighs the potential for harm. Accordingly, we hold that pesticide application is not an ultrahazardous activity warranting the application of strict liability for resulting harm. ${ }^{11}$

\section{Id. at 493 .}

215. 348 N.W.2d 540,545 (Wis. 1984 ).

216. Id. at 544

217. Id. at $545-46$.

218. Id.

219. Id. at 553 . Factually, Langan is closer to our case of the bystanding farmer than Bemnett. Bees are much more mobile than crops. In Bennert, there is no evidence that defendants' pesticides left thei

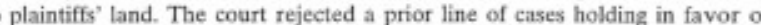
Pestiers, stating:

[C]ourts have premised their decisions that pesticide users are not liable for damage to bees on the sprayed property on the theory that bees are trespassers. We do not think that a fields wherever there is nectar and pollen. There are no means to keep them from foraging. except for short periods of time, and there is no way for land possessors to prevent bees from entering their property. 
Those jurisdictions that impose strict liability on pesticide applicators, like Washington, are more likely to hold GMO producers strictly liable than those jurisdictions, like Wisconsin, that refuse to do so. One explanation for the divergence between Washington and Wisconsin may lie in the way each state views the consideration of "common usage" as an element in the strict liability formulation. One particular element of importance in the GMO context is the "common usage" test. In Bennett, the question appears to be whether it is a common practice among agriculturalists in the community. In Langan, the question appears to be whether applying pesticides is a common practice among the general population in the community (like driving a car). Obviously, the test applied could lead to substantially different results when turning to the question whether GMO farming constitutes a common usage, which it surely is in many agricultural communities in the United States. ${ }^{200}$

Another form of strict liability might be found in cases applying nuisance per se, although courts rarely integrate strict liability terminology into their opinions. When nuisance per se is found, the defendant's conduct is deemed wrongful, with no need to balance the utility of that conduct against the harm to the plaintiff. ${ }^{2 m}$ There is some confusion in the cases as to whether the nuisance per se doctrine sanctions only conduct that is bad everywhere-no matter where the defendant's property is located-or whether it includes conduct that is wrongful because of the nature of the neighborhood where it takes place. ${ }^{m z}$ For example, a crack house would be a nuisance per se due to its

Id. at 547 n.3. The Bennett court, therefore, appears not to have based its rejection of strict liability on the location of the bees when they were poisoned. It seemingly rejects strict liability for pesticide application as a general proposition, not limited to the context of bee deaths. Nonetheless, the Wisconsin court plainly could hold for an organic crop farmer in a case factually like Langan, distinguishing Bennett without having to overrule.

220. See Crr. Fol Food SAritr, supra note 8, at 8-9.

221. A finding of nuisance per se generally equates to a summary judgment case for the plaintiff Prosstix \& KEmoN, supra note $\mathrm{III}, 878$, at 553-57. If the facts pleaded as to the defendant's engaging in a particular activity are true, and the plaintiff owns a protectible property interest, then the defendant has committed a nuisance. If plaintiff does not prove damages, however, plaintiff will be limited to nominal damages and injunctive relief. Wallace v. Grasso, 119 S.W. 3 d $567,579-80$ (Mo. C. App. 2003).

222. Sometimes a distinction is made between nuisance per se, where the action constitutes a nuisance no matter what the circumstances of where it occurs, and a nuisance per accidens, where the action becomes a nuisance because of the surroundings in which it ocrurs. See, es. Miller v. Cudahy Co., 592 F. Supp. 976, 1004 (D. Kan. 1984); Engle v. Scott, 114 P. 2 d 236, 238 (Ariz, 1941); Miniat v. McGinnis, 76i2 S.W.2d 390, 391 (Ark. C. App. 1988); Kays v. City of Versailles, $22 \mathrm{~S} . \mathrm{W} .2 \mathrm{~d} 183.183$ (Mo. C. App. 1929): Twitty v. State, 354 S.E.2d 296, 301 (N.C. C. App. 1987); Home Soles, lve, v.

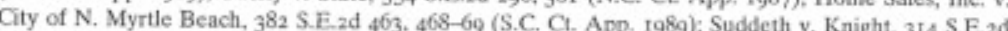

illegality in all neighborhoods. ${ }^{223}$ In contrast, a dynamite factory located in a residential neighborhood would constitute a nuisance per se, but probably not if that same factory is located in an industrial zone. ${ }^{2.4}$ It is highly unlikely that growing GMO crops in a rural area, generally used for or suitable for agricultural purposes, will constitute a nuisance per se. $^{225}$

A Texas case of the same vintage as the old weed cases illustrates the aversion some courts might have to imposing strict liability on GMO defendants. Like the weed cases, Gulf, Colorado \& Santa Fe Railway Co. v. Oakes ${ }^{236}$ is a plant pollution case, but it is much closer to our problem because it considers the spread of a cultivated plant that injures the grower's neighbor. Long ago, Texas railways planted Bermuda grass to protect their embankments from erosion. Bermuda grass spreads by runners. ${ }^{227}$ Depending upon soil conditions and other factors, sometimes it spreads aggressively. ${ }^{23}$ Once it invades farm fields adjoining the railroad rights-of-way, it interferes with crops and is difficult to eradicate. ${ }^{29}$ At trial, the plaintiff recovered damages for the injurious spread of Bermuda grass from the railroad's land. ${ }^{230}$ The trial judge had instructed the jury that the railroad was liable for the injury if it had planted the grass and the grass, "by its nature, was calculated and liable to spread to and upon adjacent lands, and damage and injure the same." ${ }^{231}$ On appeal, the court reversed the verdict. ${ }^{232}$ The plaintiff argued that the absolute liability doctrine of Rylands $v$. Fletcher supported the trial court's instruction. ${ }^{23}$ In the words of the Rylands court, the plaintiff claimed that Bermuda grass is a thing "which, though harmless while it remains there, will naturally do mischief if it escape[s] out of his land." ${ }^{24}$

223. Cf. United States v. Wade, 152 F. $3 d$ d 969,972 (D.C. Cir. 1998) (failing to reach the government's argument that a crack house is a nuisance per se).

224. The ultimate difference that the classification makes is not in the remedy afforded, but in the proof required. Nuisance,per se requires only proof of the act itself, while nuisance per acciden requires proof of the act and its consequences. See Borgnemouth Realty Co. v. Gulf Soap Corp., ${ }_{3}$ So $2 d$ 488, 490 (La. 1947); Robinson v, Westman, 29 N.W.2d I, 6 (Minn. 1947).

225. Growing GMO crops in a place where one would not expect to find them (a protected wilderness, or a small parcel in a residential neighborhood) might raise a question. However, in such settings it is not clear who or what would suffer harm from the GMO pollen.

226. 58 S.W. 999 (Tex. 1900)

227. Id. at 999 .

228. Id.

229. Id.

230. Id.

232. Id. at 1001 .

233. Id. at $999-1000$.
234. Id. at 999 . 
The Texas court, however, expressed general dissatisfaction with Rylands as a general principle, refusing to apply it to Bermuda grass:

[W] think it cannot be laid down as a rule of law, applicable to all circumstances and situations, that one who plants Bermuda grass upon his premises makes himself liable for any damage that may result to his neighbor, nor, on the other hand, that he may not be liable under some circumstances and conditions. As is said in some of the authorities, there must, in such inquires where rights and interests seem to conflict, be a balancing of them.

A bystanding farmer in Texas, therefore, may find that she must bring her claim under the nuisance balancing test of the Restatement, rather than under strict liability or nuisance per se.

Our economic analysis set forth at the beginning of this Article suggests that nuisance balancing is the most promising and prope approach. The strict liability test may not be sensitive enough to the variable factors that bear on wealth maximization. A strict liability approach might save substantial judicial costs later, however, if nuisance balancing decisions consistently establish a uniform liability rule over time.

\section{Trespass}

The intrusion of GMO pollen across boundary lines arguably constitutes trespass to land under the law of some states. The non-GMO farmer may claim that the invading pollen has interfered with her right to exclusive possession of her farmland. Despite the hope that the law of trespass may offer non-GMO farmers, traditional definitions of the scope of the cause of action counsel against liability in trespass. Traditionally, courts have distinguished trespass from nuisance, defining their elements strictly to avoid overlap between the two theories. ${ }^{236}$ A trespass consists

235. Id. at rool. Oakes may represent a refusal to transplant the English poisonous tree cases. See supra notes $132-133$ and accompanying text. In rejecting strict liability, the Oakes court left scant guidance as to how a trial court was to determine whether a particular Bermuda grass invasion was, o was not, a nuisance. At the end of the opinion, the court suggested that the question should be whether the railroad, "in planting the grass, acted as a person of ordinary prudence would have done under the same circumstances," and that this means that "the ground of liability, if one can be shown. would be negligence or other culpable conduct...." Oakes, 58 S.W. at rooz-03. Oakes can be distinguished from an invasion of GMO pollen because the injured neighbor acquires complet. ownership of the invading Bermuda grass. The Oakes court mentioned this fact as a consideration: Grass, when it spreads upon and takes root in the adjacent soil, becomes the property of the owner thereof and he may do with it as he will, and hence there is no direct violation of his absolute right to the sole use and possession of his property." Id. at IOoI. In contrast, as mentioned above, the bystanding farmer does not acquire full property rights in the patented pollen.

236. The original distinction was between the original "criminal" trespass and trespass on the case. of an intentional, unauthorized entry of a person or a tangible object on the land of another ${ }^{237}$ The invasion must be direct and the injury immediate. ${ }^{295}$ Any other intentional interference, if wrongful, is a nuisance. ${ }^{239}$ Trespass is commonly said to protect an owner's interest in exclusive possession, ${ }^{20}$ while nuisance protects the owner's interest in use and enjoyment. ${ }^{241}$ It is often unclear whether courts intend this last distinction to be an additional test, or whether it is just a way to describe a difference in practical impact that usually flows from the two types of interferences.

The traditional "direct and immediate" invasion requirement probably would insulate GMO defendants from trespass liability for two reasons. First, the passage of time between the planting of the GMO crop and its pollination makes the harm less "immediate." Second, the wind is an intervening force serving as the moving agent, making the invasion less "direct." Modern commentators, however, have suggested eliminating the "direct and immediate" requirement, ${ }^{24}$ and many modern courts have agreed. ${ }^{243}$ Thus, the process by which GMO pollen arrives on the land of non-GMO farmers may not preclude trespass liability in some

See Prosser \& Kratow, supra note $\mathrm{mI}, \$ 6$ (explaining that distinction is between trespass for immediate injury and case for some secondary causation). The authors state:

The classic illustration of the difference between trespass and case is that of a log thrown into the highway. A person struck by the log as it fell could maintain trespass against the mbling over it as it lay in 1.

237. $I d$ \& 13 , at 70

238. Baumann v. Snider, 532 S.E. 2 d 468,472 n.4 (Ga. C. App. 2000)

239. Prosser \& KeEton, supra note $111, \$ 13$, at 70 .

240. Id. (stating that trespass requirement is that invasion interferes with right of exclusive possession). and.")

. thentionally (a) enters land in the possession of the other, or causes a thing or a third person to do so ...." RestaTEMENT (SECOND) of TokTs $\$ 158$ (1965). A comment further explains:

In order that there may be a trespass under the rule stated in this Section, it is not necessary that the foreign matter should be thrown directly and immediately upon the other's land. It is enough that an act is done with knowledge that it will to a substantial certainty result in the entry of the foreign matter. Thus one who so piles sand close to his boundary that by force of gravity alone it slides down onto his neighbor's land, or who so builds an becomes a trespasser on the other's land.

REstaTEMENT (SIICOND) OF TORTs ş $158 \mathrm{cmt}$. i (1965).

243. Adams v. Cleveland-Clifts Iron Co., 602 N.W.2d 215, 224 (Mich. App. 1999) (adopting Restatement test); Lunda v. Matthews, 613 P.2d 63, 66 (Or. App. 1980) ("Direct or indirect is immaterial"); Repp, supra note 9 , at 600 (claiming modern view is that direct and indirect distinction is of no consequence in trespass actions). 
jurisdictions.

Under the modern view of trespass liability, the plaintiff farmer would have to prove three elements: (I) invasion, (2) causation, and (3) harm. ${ }^{244}$ With respect to the invasion itself, a key factor of GMO pollen is its small size. Before the middle of the last century, invasions of airborne pollutants, dust, smoke, and particulates were not trespasses. Only tangible objects large enough to be seen by the naked eyes resulted in trespass liability. More recently, a number of state courts have rejected the traditional distinction, imposing liability in trespass for airborne contaminants. ${ }^{245}$ Other courts, however, have decided to maintain the traditional distinction. ${ }^{246}$ In most states, there is no modern case law. Courts that have allowed trespass actions for the invasion of traditional industrial pollutants obviously will be predisposed to apply the same rule for bystanding farmers whose crops are damaged by GMO pollen. Conversely, courts that reject trespass for industrial pollutants will almost certainly do so for pollen.

The judicial reform to trespass law in the traditional pollution context is often not as important as one might expect. Normally, all trespasses to land are wrongful. For remedies, normally all victims can get damages (including nominal damages if no actual loss is proven) and injunctive relief if the trespass is continuing. Reformist courts, however, have not been willing to protect landowners from pollution to that extent. They usually choose not to give landowners the right to collect damages, no matter how beneficial the activity that gave rise to pollution, or the right to force the polluter to cease the activity, with no balancing of utilities. ${ }^{247}$

The second element of the trespass action-causation by one particular defendant GMO farmer-could prove difficult for the bystanding farmer. ${ }^{24} \mathrm{It}$ is important that the non-GMO farmer prove that

244 Repp, supra note 9, at 600 .

245. E.g., Borland v. Sanders Lead Co, 369 So. 2d 523, 529 (Ala. 1979) (stating that smelter's emission of lead particulates and sulfoxide gases may constitute trespass); Martin v. Reynolds Metals Co.s 342 P.2d 790, 794 (Or. 1959) (holding that aluminum plant's emission of fluoride particulates is trespass); Scanlon, supra note 7, at $6-9$ (discussing various tests applied by several states in determining whether airborne particles can result in a direct physical interference).

246. See, eg., 602 N.W.2d at 221 (dust, noise, and vibrations from iron ore mine do not result in

247. Borland, 369 So. $2 \mathrm{~d}$ at 529 (stating that plaintiff must prove substantial damage). In the leading case of Marinin, 342 P.2d at 791 , the consequence of allowing trespass was to allow the plaintiff to use a six-year statute of limitations, avoiding the two-year statute applicable to nuisance. 248. Grossman, supra note 9, at 236 ; Repp, supra note 9, at $602-03$ (explaining challenges facing
non-GMO farmers with regard to causation element). he himself did not introduce the GMO pollen to the non-GMO field, for example, by planting already-contaminated seed. ${ }^{2+9}$ Genetic testing wil likely be required to prove that the defendant, and not the plaintiff himself, is responsible for the contamination. ${ }^{250}$ In an area with a single GMO farming operation, genetic testing will be likely to successfully prove whether the singular defendant is responsible. However, if there are many GMO operations in the surrounding areas, the testing will likely not be accurate enough to prove causation. ${ }^{25 t}$ Circumstantial evidence in the form of expert testimony will be necessary to prove the causation element. ${ }^{25}$

Finally, the plaintiff farmer must prove the third element of trespass, actual damages, in order to prevail in his action. ${ }^{253}$ The plaintiff can do this in a number ways. He may, of course, offer evidence to prove that the contamination resulted in actual crop failure or damage. ${ }^{25}$

He could also show that his land has been damaged such that it is unfit for its prior intended purpose. ${ }^{355}$ Where the plaintiff is an organic farmer, he may follow this line of proof in alleging that his land has been harmed such that subsequent harvests are not marketable under the strict standards of the industry. ${ }^{296}$

In cases seeking recoveries for the unwanted spraying of pesticides and herbicides, plaintiffs have focused on negligence and strict liability. Rarely have they advanced trespass claims. One exception is Schronk v. Gilliam, ${ }^{257}$ in which defendants' airplane flew over plaintiffs' land,

249. Repp, supra note 9, at 603.

250. See Amelia P. Nelson, Legal Liability In The Wake of StarLink ${ }^{T N}$ : Who Pays In The End?, 7 Draxe J. AGric. L. 241, 258 (2002) (citing Gtaham v. Canadian Nat'l. Ry. Co, 749 F. Supp. 1300, 1318 (D. Vt. 1990)).

251. Repp, supra note 9, at 603

252. Id. The author suggests expert testimony could be used to establish the drift pattern in certain atmospheric conditions or the defendant's growing practices, noting that circumstantial evidence alone, however, will make a difficult case for the bystanding farmer. $/ d$. at 604 . For an illustration of the use of expert testimony in airborne pollutant cases, see Stevenson v. E.I. DuPont de Nemours \& $\mathrm{Ca}, 327 \mathrm{~F}, 3 \mathrm{~d} 400$ (2003).

253. REstATEMENT (SECOND) of ToRTs \& 165 (1965). This actual damages requirement applies to situations in which the invasion of the land is negligent, as in the case of pollen drift. This is opposed to trespass that involves an intentional invasion of land, which requires no actual damages be proven. See id. S 163; see, e.g., Brown Jug, Inc. v. Int'1 Bhd. of Teamsters, 688 P.2d 932, 938 (Alaska 1984) (explaining the distinction between intentional and negligent trespass and requirements of each).

254. See Scanlon, supra note 7, at 7-10 (discussing different jurisdictions' approaches to the requirement of physical versus economic damages).

255. Martin v. Reynolds Metals Co., 342 P.2d 790, 797 (Or. 1959) (finding that actual damages existed where land was rendered unfit for raising livestock).

256. See supra Part II.B (discussing market for non-GMO and organic foods).

257. 380 S.W. 2 d 743 (Tex. Civ. App. 1964). 
dropping pesticides that damaged plaintiffs' crops. ${ }^{238}$ The court affirmed a jury verdict based on trespass, ruling that plaintiff did not have to prove negligence. Schronk is an authority that could support trespass liability for GMO defendants, but it may be distinguished on the basis that the contaminant was released from an aircraft in the airspace over the crops. $^{25}$

As an alternative to trespass to land, bystanding farmers might claim injuries to their crops constitute intentional interference with personal property. In StarLink Corn Products, ${ }^{360}$ the plaintiffs pleaded conversion. The court rejected this claim for two reasons. First, the defendants, in contaminating the plaintiffs' corn, had not taken possession of the corn away from the plaintiffs. ${ }^{26 t}$ Second, the contamination had not rendered the corn valueless. ${ }^{262}$ The owners had sold their corn, but at reduced prices in markets where the corn would be devoted to uses other than human consumption. ${ }^{263}$ In rejecting conversion, the StarLink Corn Products court said that trespass to chattels (not asserted by the plaintiff) might be appropriate. ${ }^{*}$

\section{Legislative Efforts to Combat Pollen Drift}

The phenomenon of pollen drift has led advocates and opponents of

258. Defendants had wanted to spray cotton on other lands. Id. at 744 . It is not clear from the opinion whether the pesticides were discharged accidentally, or whether the pilot intentionally discharged them due to a mistaken belief that he was over the cotton. Id. at 744-45.

259. The court observed.

Whether the situation is viewed as a wrongful act after rightful entry, or as a trespass ab

initio, is not important. The entry of the fuselage, at even a privileged altitude, wis

constituted as much a part of the flipht as if appellants' aircraft had been dragging a great

scythe across the land below it. In our opinion an actionable trespass was established, and no allegation of negligence was required.

1d. at 745 .

260. 212 F. Supp. $2 \mathrm{~d} 828(2002)$.

26r. Id. at 844 .

262. Id.

264. Id. Standing crops usually are viewed as real property, not chattels. They become chattels when severed from the real estate (i.e., harvested). Arguably, plaintiff's standing crops should be when sover from the real estate (ice, hated). Argualy, plaintirs sanding crops should the likely to matter significantly whether a count proceeds under arespuss to chatels, rather the 11 is not hicly to matter significantly whether a court proceeds under trespass to chattek, rather than trespass to land. With respeet to the measurement of damages, the analysis is simpler using trespass to chattels. Plaintiff will want to collect damages equal to the reduced market value on the crop, based on prices in the commodities markets. This treats the injured property as echattels, not as land. The traditiona measure of damages for trespass to land is the difference in the market value of the land before an after the trespass. In our context, a court ought to measure damages for trespass to land based upon the reduced market value of the harvested crops. A court should quickly conclude this is appropriate, but perhaps some courts might besitate.
GMO crops to search for solutions to the growing problem of contamination. Members of at least two state legislatures have attempted to pass reform measures that would regulate the use of GMO crops in those states. For example, in North Carolina, a state in which farmers are growing approximately three million acres of GMO crops each year, an attempt was made in 2005 to give the North Carolina Department of Agriculture the sole authority to regulate and institute bans on GMO crops. ${ }^{365}$ The measure was proposed after several counties in other parts of the country instituted bans on GMO crops. ${ }^{366}$ Certain farm groups and the state government seek to place control over biotech crops in the hands of the state government only, making North Carolina a "biotechfriendly state." ${ }^{267}$ Opponents of the measure claim that it would protect no one but Monsanto and similar biotech companies. ${ }^{268}$ They cite the pollen drift phenomenon as a significant reason to be critical of the state's acceptance of GMO crops ${ }^{\text {tig }}$ As of the time this Article went to press, the bill was still being debated by the North Carolina Senate.

On the other hand, in 2005, Vermont considered the proposed Farmer Protection Act, which would have effectively held biotech seed companies liable for damages resulting from pollen drift contamination. ${ }^{270}$ Additionally, it would prevent biotech companies from suing bystanding farmers, those unwilling and unintentional patent infringers who Monsanto and similar companies currently investigate and prosecute. ${ }^{271}$ Similar bills had been proposed and subsequently defeated in Montana and North Dakota. Although the Vermont legislature passed the Farmer Protection Act, it was vetoed on May I5, 2005. ${ }^{27}$

In addition to legislative efforts to control the proliferation of GMO crops and the problems that accompany them, some biotech companies have used science to combat the pollen drift problem. For example, in 2005. Hoegemeyer Hybrids developed a new product called

65. H.R. 671, 2005 Gen. Assem., Reg. Sess. (N.C. 2005); see also David Rice, Senate Panel Debares Plants-Regulation Bill; Supponters Want to Prevent Some Crop Bans, Winston-Sal.m I. June 22, 2005, at Bi.

266. Rice, supra note 265 .

267. Id.

268. 14

270. See Andrew Barker, Vermont Plows Ahead on GE Seed Liability Law, VFrmont GuakDiax, 270. See Andrew Barker, Vermont Plows Ahead on GE Seed Liability Law, VEBMONT GUARDIAN,
Mar. II, 2005, available at http//www.mindfully.org/GE/2005/Vermont-GE-SeedMar. II, 2005,
Liabilityı

Liabilityıima

272. The Vermont Legislative Bill Tracking System, hatpj//www.leg.state,vtus/database/status/ summary.efm?Bill=S\%2E0018\&Session=2006 (last visited Oct. 22, 2006). 
"PuraMaize," which controls pollen drift by rejecting any pollen that is not its own ("non-reciprocal pollen cross-sterility"). ${ }^{\text {.J3 }}$ By using this seed, farmers can effectively grow GMO and non-GMO crops side-by-side without any fear of contamination. ${ }^{274}$ The company received a United States patent in April $2005^{275}$ and currently has patents pending in countries around the world. ${ }^{27}$ It will be available commercially nationwide in 2007 . $^{27}$

Although science may someday develop technology to diminish the effects of pollen drift, it seems unlikely that state legislatures will be able adequately to address the problem in the meantime. A legislature might, acting in what Coase refers to as its capacity as a "super firm, ${ }^{, 278}$ correctly evaluate externalities outside the competence of the common law judge, for example, the cost of lost biodiversity potentially caused by a rule of no-liability for pollen drift. If so, a legislature or administrative agency might be the logical forum to address the problem. We suspect, however, that for the time being nuisance balancing provides the most effective tool for considering all the factors relevant to social welfare in the pollen drift context.

\section{Patent Law Defenses Available to Non-GMO Farmers}

Common law is likely to provide a remedy for many farmers harmed by pollen drift. A bystanding farmer, however, may find himself the defendant in a lawsuit brought by the owner of the patent in the drifting pollen. The patent statute provides for strict liability; therefore a bystanding farmer is prima facie liable for infringement if she inadvertently makes use of patented pollen or grows a patented hybrid. Patent law, however, has long recognized a variety of defenses to infringement. Two existing defenses, unclean hands and patent misuse, may provide significant relief from patent liability for bystanding farmers. Two other defenses, the voluntary act doctrine and volenti non fit injuria, are logically applicable in patent infringement cases but are not yet judicially recognized in patent litigation. Interestingly, and consistent with the Coasean analysis conducted in Part I, these defenses

273. See Nebraska Ca. Has Developed a Seed That Prevents Cross-Pollination of GMO Crops, FARMS.COM, July 11, 2005, http://www.farms.com/readstory.asp?dtnnewsid=1232303 [hereinafter New Seed].

275. U.S. Patent No. 6,875,905 (filed Dec. 3, 2001)

276. New Seed, supna note 273 .

277. Id

278. See Consf, supra note 2, at 11 ? are most likely available only to a bystanding farmer, like our organic farmer, who does not take advantage of the benefits conferred by the adventitious drift of patented pollen. In other words, an economic justification can be offered for the application of these doctrines, even where they seem to test the limits of patent law.

\section{A. Inadvertent Use of Patented Pollen and the Voluntary} ACt DOCTRINe

Corn plants exercise no independent judgment over the pollen they use to reproduce. If patented pollen lands on the corn plants of a bystanding farmer, it will be used. Although other defenses discussed below $^{279}$ are applicable to cases of inadvertent pollen uptake, the voluntary act defense, inapplicable in the contexts of crop harvesting and selling, helps explain why no patent infringement has occurred when a bystanding farmer inadvertently grows patented crops.

In criminal law, a voluntary act is an absolute requirement for criminal liability, even where mental state is irrelevant (as is the case with patent law liability)..$^{\text {sto }}$ In most states, for example, statutory rape is a strict liability crime - that is, lack of knowledge of the victim's age is typically not a defense. For example, if a thirty-year-old female teacher has sex with a sixteen-year-old male student, it does not matter if the teacher could reasonably have thought that the student was above the age of consent. However, if the teacher is in the hospital for surgery and the visiting underage student has sex with her when she is still under anesthesia, the teacher is not guilty of statutory rape. It is not the teacher's lack of knowledge that forms the basis for the defense, but rather the involuntary nature of the teacher's participation. ${ }^{281}$ Cases applying the doctrine typically excuse reflexive acts or those performed during sleep. ${ }^{2 \mathrm{~S}^{2}}$

The voluntary act doctrine should by analogy excuse a farmer whose crops are merely the passive receptors of patented pollen, although the doctrine does not appear by that name in cases excusing civil liability. The parallel defense to strict liability in civil cases seems to be the "act of

\section{See infru Part IV.B.}

280. See Wayne Lafave, Cruminal Law 5 6.I. (c) (4th ed. 2003); see also Kevin Saunders, Voluntary Acts and the Criminal Law: Justifying Culpability Based on the Existence of Volition, 49 U. Prrr. L. REv. 443, 443-44 (Ig88) ("The concept of the voluntary act lies at the very foundation of the criminal law, since '(t) here cannot be an act subjecting a person to ... criminal liability without volition." quoting Bazley v. Tortorich, 397 So. 2d, 475, 481 (La. 1981))

281. See LAFAvE, supra note $280,86.1(\mathrm{c})$ ('(I]t is clear that criminal liability requires that the activity in question be voluntary." (citing Model. PENAL. CODE \$ 2.01(1) (1985))).

282. See Model. Penal Code 82.01 (1985). 
God" doctrine. As explained in the Restatement (Second) of Torts, strict liability (for trespassing livestock, for example) does not extend to damage "brought about by the unforeseeable operation of a force of nature (commonly called an 'act of God') or by the unforeseeable action of another animal or by the unforeseeable intentional, reckless or negligent conduct of a third person. ${ }^{2123}$ Accordingly, courts have invoked the doctrine, for example, as a defense to strict liability in finding that the owners of reservoirs "cannot be held liable where the escape of water has been caused by third party acts which the owner could neither control nor anticipate. ${ }^{1,2 \mathbb{R}_{4}}$ As in criminal law, the lack of volition on the part of the alleged wrongdoer provides the excuse. If a saboteur blows up a dam, the reservoir owner is not liable for damage caused to his neighbor's property by the escaping water.

Similarly, if the livestock of Farmer $A$ rupture the fence of Farmer $B$, and Farmer $B$ 's livestock enter Farmer $A$ 's land and do damage, Farmer $B$ is excused. These situations are apposite to the pollen drift context. If the wind blows unwanted pollen onto a bystanding farmer's fields, then the use of that pollen by the farmer's crops is similarly without the farmer's volition and should be excused. Note, however, that neither the voluntary act doctrine nor the act of God defense should be applicable to a case where the farmer goes further, by harvesting and selling these unintentionally pollinated crops, or by replanting the seeds resulting therefrom. Selling and planting are voluntary (and infringing) acts; accordingly, any excuse for these activities must be found elsewhere.

\section{B. Harvesting and Sale of Unwelcome Patented Hybrids}

Notwithstanding the strict liability nature of patent infringement, the harvesting and sale of unwanted hybrid crops by a bystanding farmer may be excusable. The doctrines discussed below have different historical roots, but share an abhorrence of a plaintiff who seeks redress in a situation where she bears primary responsibility for the alleged wrong.

\section{VOLENTI Non Fit InJURIA}

One of the most venerable doctrines in tort law establishes a defense when the plaintiff voluntarily submits himself to injury. Professo

283. RESTATEMENT (SECOND) OF TORTs \&̧ 504(3)(c) cmt. i (1965); accord Richard Wright, The Grounds and Extent of Legal Responsibility, 40 SAN DIFCO L.. REv, 1425, 1467-78 (2003) (discussing superseding causes as a limitation on legal responsibility).

284. Denis Binder, Act of God or Act of Man: A Reapprasel of the Act of God Defouse in Ton Law, Is REv. LmG. I, 64 (I996) (quoting Albig v. Mun. Auth., 502 A.2d 658, 664 (Pa. Super. C.
Terrence Ingman traces its history back to Justinian's Code, which states, "as fraud cannot be committed against anyone who gives his consent, you will in vain complain of it." ${ }^{285}$ Put slightly differently, "he who suffers damage through his own fault has no right to complain of it." According to Professor Ingman, the defense was well-established in England by the fourteenth century, ${ }^{2 / 7}$ and he provides a cogent example of its operation in 1607 .

In Horne v, Widlake, the plaintiff sued the defendant for trespassing on his land and spoiling his grass. ${ }^{258}$ The defendant pleaded that there had been a right-of-way over the plaintiff's land which the plaintiff ploughed up and sowed with wheat. ${ }^{28}$ ? The court held against the plaintiff, "for the defendant's plea is a good excuse against the plaintiff, because the plaintiff did the first tort in stopping the ancient way... [The trespass] arises from the act and tort of the plaintiff himself, and volenti non fit Injuria."

The defense is the historical antecedent to modern tort-like rules that excuse invitees from trespassing and professional boxers from committing assault. ${ }^{291}$ It is also the origin of the assumption of risk doctrine. ${ }^{192}$

The volenti doctrine seems directly applicable to the case of the bystanding farmer whose plants are pollinated by unwanted patented GMO pollen. The unwanted hybrid seeds are the result of technology that the patent owner has literally scattered to the winds, with knowledge of the most likely consequences. ${ }^{. / 3}$ Regardless of whether the behavior of a patent owner such as Monsanto is characterized as intentional or reckless with regard to the pollen drift, its own conduct is the primary cause of the alleged wrong: "[h]e who suffers damage through his own fault has no right to complain of it." ${ }^{.294}$ And, unlike the voluntary act doctrine, which requires a defendant to have remained completely

285. Terrence Ingman, $A$ History of the Defence of Volenti Non Fit Injuria, 26 JuRID. Rev. I, I (1981) ("nec umquamt volenti dolus inferatur, frustra de dol querimin").

286. Id. at 2 ("Quod quis ex culpa suo damnum sentit non intelligitur damnum sentine.").

287. See id. at $2-3$.

288. (1607) Yelverton $14 \mathrm{I}, 14 \mathrm{I}-42$ (K.B.)

289. Id.

290. Id. at 142 .

291. See Ingman, supra note 285 , at $4-5$.

292. See id. at 8-28. See generally Charles Warren, Volenti Non Fit Injuria in Actions for Negligence, 8 Harv. L Rev. 457 ( 1885 ).

293. We assume the patentee has licensed the invention to a seed manufacturer with knowledge of the seeds' future manufacture, sale, and use.

294 Sec Ingman, supra note 285 , at 2. 
passive, the defense contains no such requirement. In Horne v. Widlake, the defendant trampled the plaintiff's crops, yet still was excused. ${ }^{29}$ The same is true in modern assumption of risk cases. Arguably, therefore, the crops can be sold. Interestingly, nothing in the doctrine would distinguish organic from opportunistic farmers.

Finally, it should be admitted that the volenti defense has not yet been applied in the context of patent infringement. However, technologies that can force infringement on a passive third party like the bystanding farmer are creatures of recent vintage. There simply has been no good reason for its application until now. Employing it in the case of bystanding farmers would be another in a long line of judicia adaptations of common law and equitable defenses to suits for patent infringement. Donald S. Chisum, in his well-known patent law treatise lists several familiar non-statutory defenses that have found a comfortable home in patent suits, including fraudulent procurement, inequitable conduct, laches, estoppel, bad faith enforcement, and misuse. ${ }^{206}$ Volenti non fit injuria should plausibly join the list.

\section{Unclean Hands}

As the origin of the patent misuse doctrine, the equitable defense of unclean hands has already found its way into patent law. ${ }^{297}$ In an infringement suit by a patent owner against a bystanding farmer, an injunction preventing the farmer from harvesting or selling his crop is likely to be a key element of the requested remedy. Equitable relief, however, is subject to the unclean hands doctrine: "[h]e who comes into Equity must come with clean hands." ${ }^{\text {"98 }}$ Professor Chafee explains, "[i]n other words, since equity tries to enforce the good faith of the defendants, it no less stringently demands the same good faith from the plaintiffs." core function of the defense as protection of a defendant who was wronged by the behavior of the plaintiff. Although sometimes courts allow defendants to complain of wrongs done to third parties (rather than to the defendant), Professor Chafee notes that "much more severity is shown by law courts to the victims of torts who have themselves been

295. See supra notes $288-290$ and accompanying text.

96. See 6 Donald S. Cinsum, Chisum on Patents \$̧ 19.03, 19.03[6], 19.04, 19.05, 19.06 (1999). 297. See generally Aptix Corp. v. Quickturn Design Sys., Inc., 269 F.3d, 1369 (Fed. Cir. 200I) (finding that submission of falsified evidence in litigation barred enforcement of the patent against the efendant, but did not render the patent invalid against other parties).

298. Zechariah Chafec, Jr., Coming into Equity with Clean Hands, 47 Mrch. L. Rev, 877.877 (1949)

299. Id. transgressors." ${ }^{n / 0}$

In the context of patent infringement claims, any equitable relief sought by a patentee should have to satisfy the unclean hands standard. In fact, Judge Richard Posner of the Seventh Circuit recently acknowledged in a patent infringement case the doctrine's presence as an equitable defense: "I believe that as a matter of fundamental principle it must be a defense to a charge of patent infringement that the patentee caused the infringement." ${ }^{30}$ "In the case before the district court (where Posner sat by designation), the plaintiff Smithkline held one of several patents on the blockbuster antidepressant Paxil, and claimed that the defendant had infringed that patent. ${ }^{300}$ The district court dismissed the plaintiff's case, finding that Smithkline's widespread distribution of the drug had contaminated the defendant's research and production environments through a process of natural crystallization. ${ }^{303}$ The defendant could not help but infringe and was therefore excused from liability. ${ }^{304}$ Posner's decision was affirmed by the Federal Circuit on other grounds ${ }^{305}$ but the appellate court went on to speak with some approval of Posner's rationale: "[i]n this unique and unprecedented circumstance, the trial court understandably reached out to find an equitable remedy to protect [the defendant]."

The case of the Paxil defendant and the bystanding farmer fall close to the historical core of the unclean hands doctrine, where the plaintiff complaining of the patent infringement is likely to be the same party primarily responsible for it. Patented seeds are licensed to be sold and planted, and the production of pollen and process of hybridization are common knowledge. Inadvertent contamination is a surprise to no one. Consistent with economic analysis, we would suggest that the defense be available to farmers harmed by pollen drift, but not by those that benefit. The unclean hands defense should not be available to an opportunistic

300. Id, at 904-05. 30l. Smithkline Beechant Corp. An but that even if it bad, equitable defense of unclean hands (inould bar plaintiffs recovery).$$
\text { 302. Id. at 1013. }
$$

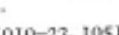$$
\text { 303. See id. at } 1019-10
$$

305. See Surthtine Beccham Corp. v. Apotex Corp., 365 F.3d I306, 1316-20 (Fed. Cir. 2004) 305. See Sablatine Ba been in clinical trials and thus in "public use"). The case was subsequently (linding that the drug tad oninion, but the conclusion was based on yet another ground-"inherent affirmed by an en tanc opinion, But v. Apotex Corp., 403 F. 3d 1331, 134I-46 (Fed. Cir. 2005) (en banc).

306. Id. at 1316 . 
farmer whose own hands are arguably "unclean."

\section{Patent Misuse}

The defense of patent misuse, judicially derived from the doctrine of unclean hands, ${ }^{y m}$ renders a patent unenforceable when the patentee has engaged in conduct designed to "extend[] the patent beyond its lawful scope." As one court put it, the "rationale of the doctrine is a rejection of the concept of the patent as an absolute property right in favor of its definition as a right which must not be exercised in a manner not inconsistent with the constitutionally-defined purpose for which it was conferred, i.e., to 'promote the Progress of [the] useful Arts." ${ }^{m \infty}$ Professor Chisum suggests that the question to ask in patent misuse cases is whether "the practice in question [should] be treated as an appropriate exercise of the patentee's statutory patent rights?"

In the case of inventors of new plants, patent law provides a means by which they can attempt to recoup the costs of research and development. If the new plant constitutes an improvement over prior similar plants, ${ }^{311}$ then the inventor should find a ready market for the improved good. Patent law provides a legal means to protect that market. As noted above, Monsanto has patented a corn plant that resists the herbicide Roundup. ${ }^{312}$ Many farmers who use Roundup are eager to buy the patented "Roundup-Ready" seeds in order to increase their yields. Patent law gives Monsanto the legal means to assure that it will be the sole source of Roundup-Ready seeds to farmers wanting to plant them.

307. See Morton Salt Ca. v. G.S. Suppiger Co, 314 U.S. $488,492-94$ (1942) (holding patent unenforceable and linking patent misuse defense to unclean hands doctrine) ( CR. Bard, Inc, paten Sys., Inc., 157 F.3d 1340, 1372 (Fed. Cir. 1998) ("The defense of patent misuse arises from the equitable doctrine of unclean hands...."); B. Braun Med., Inc. v, Abbott Lab., 124 F. 3 d 1419 , 1426 Fed. Cir. 1997) (holding patent misuse is an extension of the equitable doctrine of unc $^{2}$ I4I9, 1426 W.L. Gore \& Assoc, Inc v. Carlisle Corp., 529 F.2d 6r4, 622 (3d Cir. 1976) ("The doctrine of pands), misuse is an extension of the equitable doctrine which denies judicial relief the doctrine of patent court with 'unclean hands "'=) (

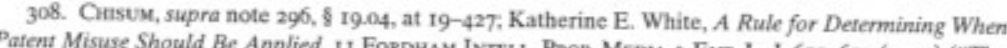
Patent Misuse Should Be Applied, II FordHAs INTELL. Pwop. Medu \& ENT. L. J. 671, 673 (2001) ("The patent misuse doctrine prohibits efforts by a patentee that seck to extend a patent beyond the original
scope of its grant.").

309. Hensley Equip. Co., Inc. v. Esco Corp., 383 F.2d 252, 26 I (5th Cir. 1967) (quoting U.S. Const. it. 1,58 ).

310. See CHisuse, supra note 296, 5 t $19.04[2]$.

3II. An invention is patentable whether or not it constitutes an improvement over the prior art (or has any value at all). See 35 U.S.C. $585101-103$ (2005) (establishing novelty, usefulness, and non312. Sas prerequisites to obtaining patent).

312. See supra notes $73-75$ and acoompanying text.
Patent law effectively grants Monsanto exclusive rights to this market. ${ }^{313}$

Nothing in patent theory, however, suggests that Monsanto should have the legal right to force unwilling farmers to grow Roundup-Ready crops against their will. Were Monsanto able to enjoin the harvesting and sale of all bystanding farmers' crops, Monsanto would be enlarging its market far beyond what patent law is designed to protect. A bystanding non-GMO or organic farmer has no desire to make, use, sell, offer for sale, or import patented seeds or plants. Given the premium such farmers receive for selling their non-GMO or organic crops, ${ }^{314}$ they vigorously want nothing to do with such seeds or plants. In other words, bystanding farmers do not constitute any part of the market that patent law sets aside for owners of patented pollen, seeds, and plants. A patent infringement suit against a bystanding farmer constitutes an improper attempt on the part of the patent owner to expand the scope of the patent beyond its legal limits-the classic definition of patent misuse. Consistent with our economic analysis, it should be available to victims of pollen drift, but not to opportunistic beneficiaries.

The closest analogy in existing law involves cases in which patent owners have attempted to force liability on unwitting users of technology through a standard settings process. ${ }^{315}$ In In re Dell Computer Corp., the Federal Trade Commission (FTC) considered Dell's behavior before the Video Electronics Standards Association (VESA). ${ }^{316}$ In the course of participating in the VESA standard setting process for a computer bus design, eventually known as the VL-Bus, Dell certified in writing that it held no patents, nor planned to hold any patents, that the VL-Bus would infringe. ${ }^{137}$ Free from concerns that computer firms would have to pay Dell a royalty in order to conform to the proposed standard, VESA approved the VL-Bus. ${ }^{318}$ Once the standard was in place, however, Dell revealed it held a patent on one key part of the VL-Bus technology. ${ }^{319}$ Dell's fraudulent representations before VESA threatened to put all conforming firms in the industry in violation of Dell's patent rights. ${ }^{320}$ In order to conform to the standard, Dell's competitors would have to

313. See 35 U.S.C. 8271 (2005) (detailing rights of patent owners).

314 See supra note 7.

315. See Janice Mueller, Patent Misuse Through the Capture of Industry Standands, 17 Berkeley Tech. L.J. 623. 63I (2002) (arguing that failure to reveal relevant patent rights in course of standard setting should constitute patent misuse).

316. 121 F.T.C. 616, 617 (1996).

317. Id.

318. See id, at 617,624

319. Id. at 617.

320. See id. at 624 n.2. 
infringe or pay Dell a licensing fee. ${ }^{311}$ The FTC found that Dell's behavior was anticompetitive and that its patent rights provided no legal excuse for its behavior. ${ }^{32}$ As a result, the FTC ordered Dell to license its patented technology free-of-charge to those wishing to conform to the VL-Bus standard. ${ }^{323}$

It is every patent owner's dream to see its patented technology adopted as the sole acceptable industry standard. Where a standard setting body objectively and with full information adopts a proprietary standard, the patent misuse doctrine is not implicated. When the patent owner acts wrongfully, however, in advocating a proprietary standard, the patent misuse doctrine may render the patent unenforceable against putative infringers who must conform with the standard. ${ }^{324}$ In the standard settings cases, ${ }^{325}$ the key factor is the unilateral imposition of legal duties on unwitting parties, just as in the case of the patentee and the bystanding farmer. But the case of the farmer is even more compelling. Sometimes firms can avoid a standard or design around it, ${ }^{306}$ but the bystanding farmer who discovers that his fields are full of allegedly infringing plants has been completely captured by the patent owner. He has no choice but to plow under his fields or pay a licensing fee.

Some important commentators have expressed doubts about the defense of patent misuse, ${ }^{327}$ but their complaints are usually directed at the overlap between the typical patent misuse case and antitrust law ${ }^{\text {sa }}$ The majority of patent misuse cases allege that the patent owner has used the patent to violate antitrust law, and Professor Mark Lemley's critique of patent misuse doctrine is representative. He argues that in

321. Id.

322. Id. at $624-25$

323. Id. at $620-21$.

324. See Mueller, supra note 315, at 63I (arguing that failure to reveal relevant patent rights in course of standard setting should constitute patent misuse).

325. See, e.g., Rambus Inc. v. Infineon Tech. AG, 318 F. 3d to8 I, 1084 (Fed. Cir. 2003) (finding that allegations that advocate for industry standard breached a duty to disclose its pending paten applications)

326. See Dell, 121 F.T.C. at 618, 619 (order indicates that members delayed implementing the standard and might have tried to design around it).

327. See, eg., Patricia Martone \& Richard Feustel, Jr., The Patent Misuse Defense-Does It Strit Have Vitality?, 832 Pracnsing L. Inst. IntuLL. Phor. ANrTrust 145, $201-02$ (2005)

328. See, eg., Robin Feldman, The Insufficiency of Antitrust Analysis for Patent Misusce, 55 Husninas L.J. 399, 400 (2003) (arguing that patent misuse and antitrust cannot be alleviated by requiring the application of antitrust rules to test for patent misuse); Mark Lemley, Comment, The Economic Irrationality of the Patent Misuse Doctrine, 78 CaL. L. REv, 1599, 1599 (1990) (arguing that antritrust laws can serve the same purpose as the patent misuse doctrine. antitrust-style cases the misuse "sanction imposed bears no relation to the injury caused... [It] duplicates antitrust remedies in many cases, leading to an excessive level of deterrence... [and] often pays the sanction as a windfall to an unrelated third party, thereby encouraging infringement while failing to compensate those actually injured." Although we are sympathetic to the view that the patent misuse doctrine, to the extent it overlaps with antitrust law, may be "economically irrational, ${ }^{n 30}$ to use Lemley's term, the bystanding farmer does not come to court dressed as an antitrust victim.

First, the bystanding farmer who asserts the patent misuse defense alleges that he is the victim of an illegal nuisance or trespass, not the victim of an illegal monopoly, so there is no duplication with antitrus remedies. Second, there is no imbalance between the injury caused to the farmer and the remedy he seeks. If the misuse defense negates injunctive relief, the farmer is merely freed to sell his crops at the lower GMO price. If he also counterclaims for damages, he will only be entitled to the actual reduction in the value of his crop due to the contamination. ${ }^{331}$ There is no double recovery, and the patentee may continue to exploit and protect his natural market for patented seeds and plants - those who affirmatively desire to plant them. Finally, there can be no windfall in the situation where the bystanding farmer has gained no advantage in any way by the windblown pollen. On the other hand, a bystanding farmer who takes advantage of the patented technology by either replanting patented seeds or taking advantage of herbicide resistance qualities of the patented hybrids should not be able to assert the defense.

Applying the patent misuse defense in the case of the bystanding farmer would also have the salutary effect of giving some much-needed content to a neglected half of the typical formulation of the doctrine. Professor Chisum gives the universally accepted formulation of the patent misuse defense: "A patent owner may [not] exploit a patent in an improper manner by violating the antitrust laws or extending the patent beyond its lawful scope." ${ }^{132}$ Courts and commentators have had a hard time imagining how a patent owner might extend the scope of its patent in any way other than committing an antitrust-style violation. The unlawful extension clause in the patent misuse formulation has done little work. The situation of the bystanding farmer, and perhaps the

329. Lemley, supra note 328 , at 1600 .

330. Id. at 1599 .

331. See sippra notes $253-256$ and accompanying text.

332 See CHISUM, supra note $296,819.04$ (emphasis added). 
victim of a flawed standard setting process, suggest what an unlawful extension of the patent grant can look like outside the antitrust setting. Both parties allege wrongs (trespass, nuisance, fraud) that do not require any finding of an actionable monopolization, while still satisfying the core equitable concerns underlying the doctrine,

Patent misuse provides the most doctrinally compelling defense for bystanding farmers who inadvertently commit patent infringement, and it also suggests a scheme of liability consistent with our economic analysis The organic farmer who is harmed by pollen drift presents a strong case for the application of the patent misuse doctrine. The opportunistic farmer who intentionally exploits pollen drift presents a much weaker case.

\section{Conclusion}

When Ronald Coase wrote The Problem of Social Cost, the archetypical problems between neighbors that concerned him involved wandering cows trampling farmer's fields and sparks flying off of trains to ignite crops. The widespread drift of genetically modified pollen presents a similar economic problem, but on a much vaster scale that threatens a multi-billion dollar agricultural industry producing organic and other non-GMO crops for markets in Japan, Europe, and the United States. Nonetheless, the simple two-party game modeled by Coase still provides valuable insights into how pollen drift disputes between neighbors should be settled. In a world of high transaction costs, nuisance law can provide an effective mechanism for weighing the costs and benefits of liability in any particular case. In order to determine the desirability of imposing liability, a decision-maker must consider the farming methods at issue, typical crop yields, variable costs of production, market values of crops, the availability of alternative seeds and protective measures, and the magnitude of each farmer's switching costs. In theory, a common law court applying nuisance balancing doctrines may be better situated to maximize net social welfare than a state or federal legislature.

The federal legislature, however, has spoken, at least as regards the patentability of the GMO pollen that may drift unbidden across property lines. The genetic structure of such pollen is often proprietary, and the strict liability nature of patent infringement arguably establishes a onesize-fits-all rule that disadvantages non-GMO farmers at every turn. Consistent with our economic analysis, we find that equitable doctrines within patent law provide a defense for a bystanding farmer who has been harmed by pollen drift, but not for one who has opportunistically benefited. Coase proved that in a world of high transaction costs, a rule that fixes liability without regard to variations in the underlying facts is likely to be inefficient. The nuanced role for patent law that we describe has support in existing doctrine, is consistent with Coase's discussion of social cost, and maintains the game theoretic equilibria we establish in the two-player neighbors pollen drift game. 